\title{
Hydrological functioning of western African inland valleys explored with a critical zone model
}

\author{
Basile Hector $^{1}$, Jean-Martial Cohard ${ }^{1}$, Luc Séguis ${ }^{2}$, Sylvie Galle ${ }^{1}$, and Christophe Peugeot ${ }^{2}$ \\ ${ }^{1}$ Univ. Grenoble Alpes, IRD, CNRS, Grenoble INP, IGE, 38000 Grenoble, France \\ ${ }^{2}$ HSM, IRD, Univ. Montpellier, CNRS, 34000 Montpellier, France
}

Correspondence: Basile Hector (basile.hector@ird.fr)

Received: 23 April 2018 - Discussion started: 18 May 2018

Revised: 13 September 2018 - Accepted: 9 October 2018 - Published: 14 November 2018

\begin{abstract}
Inland valleys are seasonally waterlogged headwater wetlands, widespread across western Africa. Their role in the hydrological cycle in the humid, hard-rock-dominated Sudanian savanna is not yet well understood. Thus, while in the region recurrent floods are a major issue, and hydropower has been recognized as an important development pathway, the scientific community lacks precise knowledge of streamflow $(Q)$ generation processes and how they could be affected by the presence of inland valleys. Furthermore, inland valleys carry an important agronomic potential, and with the strong demographic rates of the region, they are highly subject to undergoing land cover changes. We address both the questions of the hydrological functioning of inland valleys in the Sudanian savanna of western Africa and the impact of land cover changes on these systems through deterministic sensitivity experiments using a physically based critical zone model (ParFlow-CLM) applied to a virtual generic catchment which comprises an inland valley. Model forcings are based on 20 years of data from the AMMA-CATCH observation service and parameters are evaluated against multiple field data ( $Q$, evapotranspiration - ET -, soil moisture, water table levels, and water storage) acquired on a pilot elementary catchment. The hydrological model applied to the conceptual lithological/pedological model proposed in this study reproduces the main behaviours observed, which allowed those virtual experiments to be conducted. We found that yearly water budgets were highly sensitive to the vegetation distribution: average yearly ET for a tree-covered catchment $(944 \mathrm{~mm})$ exceeds that of herbaceous cover $(791 \mathrm{~mm})$. ET differences between the two covers vary between $12 \%$ and $24 \%$ of the precipitation of the year for the wettest and driest years, respectively. Consequently, the tree-covered catch-
\end{abstract}

ment produces a yearly $Q$ amount of $28 \%$ lower on average as compared to a herbaceous-covered catchment, ranging from $20 \%$ for the wettest year to $47 \%$ for a dry year. Trees also buffer interannual variability in ET by $26 \%$ (with respect to herbaceous). On the other hand, pedological features (presence - or absence - of the low-permeability layer commonly found below inland valleys, upstream and lateral contributive areas) had limited impact on yearly water budgets but marked consequences for intraseasonal hydrological processes (sustained/non-sustained baseflow in the dry season, catchment water storage redistribution). Therefore, subsurface features and vegetation cover of inland valleys have potentially significant impacts on downstream water-dependent ecosystems and water uses as hydropower generation, and should focus our attention.

\section{Introduction}

It is widely recognized that wetlands exert a strong influence on the hydrological cycle. However, they hardly support generalization in their functioning, according to their different types and settings, and the limited availability of hydrological observations (Bullock and Acreman, 2003). In sub-Saharan western Africa, "Bas-fonds", or inland valleys, are seasonally waterlogged wetlands located at the headwater of streams and cover 22-52 Mha (Andriesse et al., 1994). They can be found on the whole continent, although they have different names, such as dambos, mbuga, inland valleys, or valley bottoms. Their role in the hydrological cycle is still unclear and lacks significant attention. This is particularly true for the humid Sudanian zone, mostly located on 
hard-rock lithology with rather shallow water tables and lowcapacity aquifers (MacDonald et al., 2012) where all components of the critical zone are tightly linked (e.g. tree root systems are likely to be connected to the water tables; Mamadou et al., 2016; Richard et al., 2013). There, for instance, the role of inland valleys in streamflow generation is still poorly understood, while they are suspected of providing most of the observed streamflow as baseflow through exfiltration of perched seasonal water tables (Séguis et al., 2011).

Streamflow generation mechanisms deserve more attention, as (1) the region suffers from severe floods, which affect an increasing number of people (Di Baldassarre et al., 2010), and (2) hydropower development is also ongoing (Cervigni et al., 2015) and is recognized to be a fundamental large-scale source of energy for the development of sub-Saharan Africa (http://www.worldbank.org/en/topic/ hydropower/overview, last access: April 2018) (World Bank, 2009).

Moreover, the strong western African demographic rates (2.6\% on average in the period 2000-2010) imply rapid changes in land use and land cover (LULC) (FAO, 2012). For instance, about $42 \%$ (or $8 \%$ ) of forested land (or non-forested vegetation) was converted to agricultural land (which amounts to an increase of more than $11 \%$ ) in the Sudanian savanna between 1975 and 2000 (Eva et al., 2006). This is also likely to affect the functioning of inland valleys, although it is still unknown to what extent.

Despite the possible role of inland valleys in the hydrological cycle, they carry an important agronomic potential currently underexploited (Katic et al., 2014; Rodenburg et al., 2014). Due to their high water content, they can be cultivated offseason, and thus they buffer the high climatic variability of the area (Nyamadzawo et al., 2015) as well as human pressure on uphill plots located closer to the villages (Lounang Tchatchouang et al., 2014). However, inland valley exploitation limits should be carefully studied, as overexploitation may have consequences for these specific ecosystems (Böhme et al., 2016; Brouwer et al., 2014; Wood, 2006). Rodenburg et al. (2014) estimate that production derived from less than $10 \%$ of the total inland valley area over Africa could meet the total current demand for rice in Africa. In these studies, little is mentioned about water exploitation sustainability. This is due to the heterogeneity of inland valleys and the difficulty of capturing fundamental hydrological processes to be generalized. This again calls for documenting water redistribution processes within inland valleys, so as to include water use sustainability in the process of inland valley selection and cultivation (Böhme et al., 2016; Schmitter et al., 2015).

Headwater inland valleys are characterized by a rapid decrease in permeability with depth due to the accumulation of clays, which is ultimately associated with a low-permeability layer, allowing the formation of perched water tables in the valley thalweg (Blavet, 1997; Brabant, 1991; Hector et al., 2015; von der Heyden and New, 2003; Von Der Heyden,
2004). The hydrology of inland valleys is also controlled by classical catchment features like vegetation distribution and the functioning of contributive areas (Von Der Heyden, 2004). For instance, concerning vegetation distribution, Balek (2006) reports on increased flood flow when trees were removed from two of their observed catchments. The fast LULC changes occurring today call for the scientific community to clearly understand the role of different vegetation distributions and the impact of their changes on the hydrology of inland valleys. These interactions between flow generation and vegetation require study of the hydrological functioning of inland valleys in an integrated, critical zone (CZ)like approach. Concerning contributive areas, the dominance of baseflow in the hydrology of inland valleys calls for investigation of the properties of subsurface regions prone to contributing to streamflow through water exfiltration in the valley thalweg.

As a complement of $\mathrm{CZ}$ observations, physically based $\mathrm{CZ}$ models are appropriate tools to study the functioning of a hydrosystem (e.g. Kollet and Maxwell 2008; Srivastava et al. 2014). These models explicitly link all hydrological compartments of the $\mathrm{CZ}$, from the deep impermeable bedrock to the top of the canopy, and provide a robust framework to conduct virtual experiments (Weiler and McDonnell, 2004).

In this paper, we seek to address the following two questions: (1) what are the main characteristics of the hydrological functioning of inland valleys in the Sudanian savanna of western Africa? (2) What is the impact of LULC changes on such systems? The approach undertaken here is to build a set of virtual experiments in an idealized elementary V-shaped catchment to test the sensitivity of a physically based CZ model to different features: (a) the presence of the low-permeability layer in the valley thalweg, which characterizes inland valleys, (b) the pedology of contributive areas and (c) the vegetation distribution (from natural woodland cover to herbaceous-like fallow/crop cover). This idealized elementary V-shaped catchment is built based on the main features of elementary catchments comprising an inland valley (topography, clay lens, vegetation distribution), but also following a highly instrumented elementary catchment for which we previously built a conceptual lithological/pedological model (Hector et al., 2015).

In the first section, we briefly discuss the physical environment and how we model it over a 7-year period using a physically based $\mathrm{CZ}$ model. Then, we present the results of a single simulation, which are compared to observations from the elementary headwater catchment, available within the AMMA-CATCH observation service (www.amma-catch.org (last access: 23 October 2018), Galle et al., 2018; Lebel et al., 2009, AMMA-CATCH, 1990) and several campaigns, to show that the model is able to reproduce to a large extent the complex critical zone behaviour. We finally use the results of a set of virtual experiments to infer the model sensitivity to the main inland valley features (presence of a clay layer in the valley thalweg and hydrodynamic properties of the contribu- 
tive areas) and the vegetation distribution likely to evolve, and discuss these results.

\section{Material and methods}

\subsection{Description of the physical environment}

In this section, we briefly describe our conceptual representation of the main soil and vegetation characteristics found in the hard-rock basement areas of the Sudanian climatic region (yearly precipitation amount between 700 and $1400 \mathrm{~mm}$ ) dominated by metamorphic settings. This ecophysical model is built following the literature of the region and on inland valleys and the work of Hector et al. (2015), who studied and described the functioning of an elementary catchment in northern Benin, the Nalohou catchment $\left(0.16 \mathrm{~km}^{2}\right)$. This catchment is part of the regional AMMACATCH observatory, which belongs to the OZCAR network of critical zone observatories (Gaillardet et al., 2018). See for instance Fig. 13 in Hector et al. (2015) for a conceptual sketch of their understanding of the Nalohou catchment: during the dry season the permanent water table is disconnected from the inland valley, while during the wet season, the permanent water table rises and a shallow perched water table appears in the inland valley which is fed by both rainwater infiltration and lateral subsurface transfers. This specific behaviour is representative of inland valley functioning in similar geological/climatic contexts (see e.g. Brabant, 1991, in Cameroon, Diatta, 1996, in Ivory Coast or Giertz and Diekkrüger, 2003, in the other location in Benin). In the Nalohou case, lateral subsurface contributions to the inland valley differ from each bank: contributions from the layered left bank (highly permeable hardpan over low-permeability clay-rich horizons) exceed contributions from the sandier right bank. Figure 1a shows the actual catchment shape as a black line and cross sections of Fig. 1b-c summarize the internal structure of the catchment.

\subsubsection{Soil layers and properties}

Our conceptual model of the physical environment is made up of three layers through depth (H1: 0-0.5, H2: 0.5-2, H3: $2-10.5$ m, Fig. 1b-c), to which we prescribed specific hydrodynamic properties in a deterministic way and following the literature, but is also based on numerous field and laboratory measurements by Hector (2014), Richard (2014) and Robert (2012) in the same area (Table 1). In the following text, we refer to sand-like and clay-like hydrodynamic properties in a broad sense: sand-like relates to highly permeable/lowretention media and clay-like relates to low-permeable/highretention media. The reader may refer to Tables 1 and 3 for actual property ranges and values.

The thicknesses of the two shallowest soil layers (H1 and H2) are well defined from observations in the Nalohou catchment, and seem in accordance with other locations in (sub)tropical humid regions (de Condappa et al., 2008). The thickness of the deeper layer (H3) is that of the regolith, located above the fissured basement and the hard-rock basement, following Lachassagne et al. (2011).

\section{Layer H1}

In the tropical-humid Sudanian climate, topsoils are usually permeable, due to microfauna bioturbation or soil work from farmers (Giertz and Diekkrüger, 2003; Richard, 2012; Robert, 2012). As a consequence, the infiltration-excess overland flow is very limited in the area (e.g. Giertz et al., 2006; Masiyandima et al., 2003). The topsoil layer, H1, is therefore permeable, with sand-like soil hydrodynamic properties. Some authors note a significant relationship between saturated hydraulic conductivity and land cover in the area (Giertz et al., 2005; Giertz and Diekkrüger, 2003; Richard, 2014), but in a limited range (less than 1 order of magnitude). The $\mathrm{H} 1$ layer is thus considered laterally homogeneous in this study.

\section{Layer $\mathbf{H} 2$}

The second layer $(\mathrm{H} 2)$ is usually more variable laterally, and variations in clay content in this potential illuviation layer (a clay-accumulation horizon, as described by de Condappa et al., 2008) may generate perched water tables (e.g. Giertz et al., 2006). In this layer, some macroporous hardpan units with high permeability may also be found (Bonsor et al., 2014; Hector et al., 2015).

It is beyond the scope of this study to analyse the effect of this layer $(\mathrm{H} 2)$ on the hydrological processes. There is an extensive literature using the same critical zone modelling framework that provides insights into the effect of lateral variability of soil properties through dedicated sensitivity studies (Atchley and Maxwell, 2011; Meyerhoff and Maxwell, 2011; Meyerhoff et al., 2014; Gilbert et al., 2016). We therefore chose to consider a rather sandy, permeable layer to mimic a hardpan unit behaviour (as part of the polycyclic soil profile described by Faure and Volkoff, 1998), and favour quick lateral subsurface transfer, which has been observed in the area (e.g. Hector et al., 2015; Masiyandima et al., 2003 and Séguis et al., 2011).

\section{Layer H3}

The composition of the third layer (H3) is variable laterally. On the one hand, there is a low-permeability, clayey horizon, similar to what is observed by Hector et al. (2015) and Wubda et al. (2017) in the western half of the Nalohou catchment, and also described as a major feature from larger-scale observations by Faure and Volkoff (1998). On the other hand, there is a clay-eluviated, saprolite-like, sandy horizon, which is expected to produce a strongly contrasted behaviour. It is also similar to what is observed in the eastern half of the 


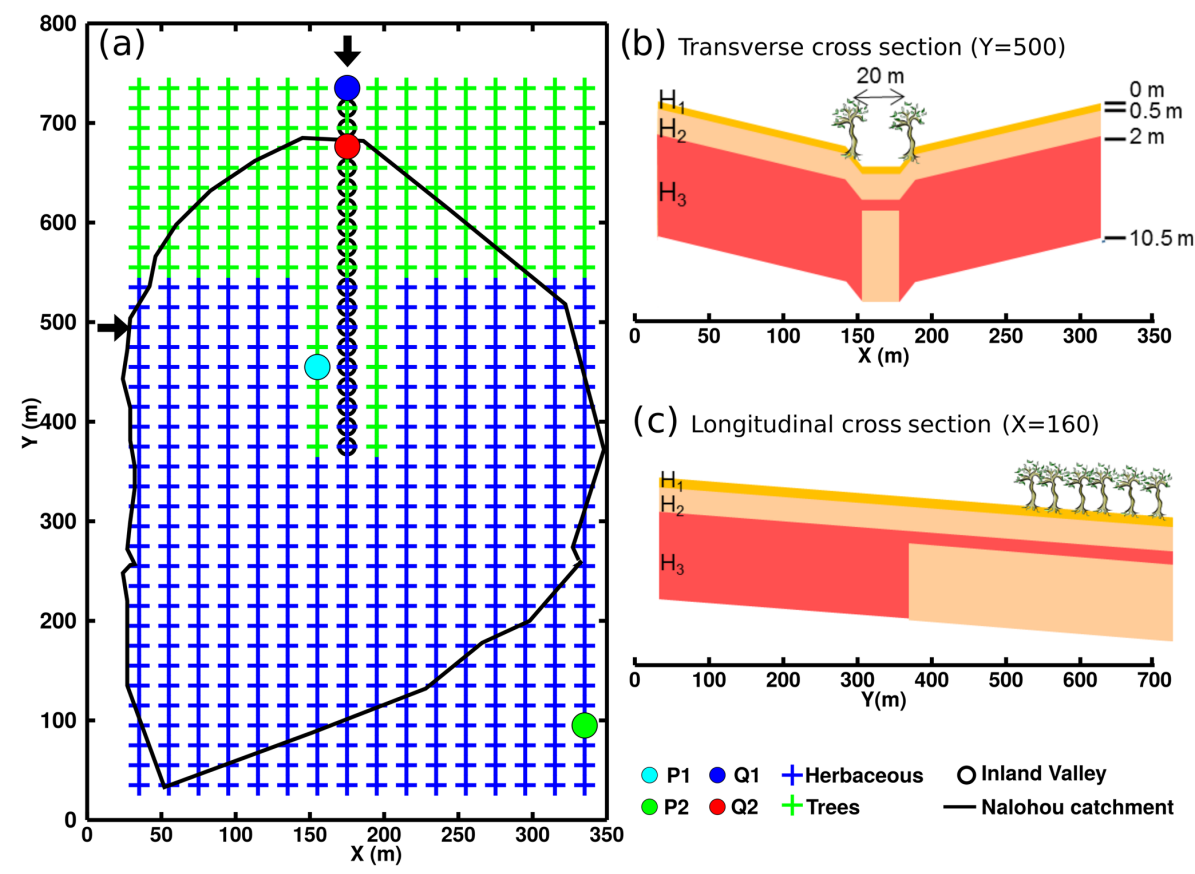

Figure 1. (a) Catchment mesh. Blue and green crosses indicate the vegetation distribution for the reference case. Inland valley cells are shown as black circles. $P$ are water table sampling locations and $Q$ are streamflow sampling locations. (b, c) Domain cross sections schematically made up of three soil types: high-permeability sandy soils (yellow), hardpan or fissured basement (orange) and low-permeability clay accumulation (red).

Nalohou catchment, and is the second major feature from larger-scale observations by Faure and Volkoff (1998).

\section{Inland valley}

The inland valley is located in the downstream part of the valley thalweg (circles of Fig. 1a). It has a specific $\mathrm{H} 1 / \mathrm{H} 2 / \mathrm{H} 3$ sequence. It usually consists of sandy upper horizons. H1 and $\mathrm{H} 2$ layers are the same as elsewhere, and are considered to be of a sandy nature and to favour quick vertical and lateral transfers, as observed in the field. At about $2 \mathrm{~m}$ depth, in the upper part of the $\mathrm{H} 3$ layer just below the $\mathrm{H} 2$ horizon, is a low-permeability, clayey layer, which actually characterizes the inland valley. This allows the formation of perched water tables during the rainy season (Masiyandima et al., 2003). Such a shallow drainage system is the main contributor to baseflow, which represents roughly $80 \%$ of total streamflow for such a catchment (Giertz et al., 2006; Hector et al., 2015; Kamagaté et al., 2007; Séguis et al., 2011). This clay-rich accumulation horizon is often found above a poorly weathered horizon (Brabant, 1991), as is the case in the Nalohou catchment. Therefore the H3 layer underneath the inland valley is made of a low-retention, high-permeability fissured basement (in the sense of Lachassagne et al., 2011).

\section{Hydrodynamic properties}

In a thesis work, Hector (2014) summarized the variability of field measurements to build up classes of main soil/lithology units for the three main layers identified in this study (Table 1). Hydrodynamic parameters (following Van Genuchten, 1980) for this study are shown below in Table 3. Saturated conductivities of saprolite and fissured basement in $\mathrm{H} 3$ are given by the range of observations derived from both pumping tests and magnetic resonance soundings in the area (Vouillamoz et al., 2014).

\subsubsection{Topography}

At the Upper Ouémé catchment scale $\left(14300 \mathrm{~km}^{2}\right.$, which includes the Nalohou area), comprising many inland valleys (Giertz et al., 2012), a slope analysis from the 3" (about $90 \mathrm{~m}$ ) Hydrosheds DEM (www.hydrosheds.org, last access: 24 October 2018) provided an average slope of $2.6 \%$. In nearby Togo in a similar geomorphological context (Région centrale, $13000 \mathrm{~km}^{2}$ ), Runge (1991) noted that $80 \%$ of the surface has slopes in the range $1.7 \%-5.2 \%$. The slope along the transverse axis ranges from $1.7 \%$ to $3.5 \%$ and from $3.5 \%$ to $5.2 \%$ along the longitudinal axis. They further identified inland valleys as developing preferentially in the range $3.0 \%-4.4 \%$ along the steepest axis. For the specific Nalohou catchment, mean longitudinal slope (N-S) is $4 \%$ and mean transverse (E-W) slope is $2 \%$, according to a $5 \mathrm{~m}$ lateral- 
Table 1. Ranges of hydrodynamic properties in the area, following Van Genuchten (1980). From Hector (2014).

\begin{tabular}{lrrrrr}
\hline & $\theta_{S}$ & $\theta_{r}$ & $\mathrm{Ks}\left(\mathrm{m} \mathrm{s}^{-1}\right)$ & $\mathrm{hg}(\mathrm{m})$ & $n$ \\
\hline H1 & $0.35-0.45$ & $0.01-0.05$ & $5.8 \times 10^{-6}-5.7 \times 10^{-5}$ & $0.2-0.6$ & $1.6-2.2$ \\
H2 & $0.35-0.45$ & $0.05-0.1$ & $1.2 \times 10^{-7}-3.5 \times 10^{-5}$ & $0.2-0.6$ & $1.5-1.8$ \\
H3 (clay) & $0.4-0.5$ & $0.05-0.1$ & $1.2 \times 10^{-8}-1.2 \times 10^{-6}$ & $1-1.5$ & $1.15-1.5$ \\
H3 (saprolite) & $0.4-0.45$ & $0.05-0.1$ & $1.2 \times 10^{-6}-5.7 \times 10^{-5}$ & $0.7-1.5$ & $1.2-2$ \\
H3 (inland valley) & $0.2-0.35$ & $0.01-0.05$ & $1.2 \times 10^{-6}-5.7 \times 10^{-5}$ & $0.7-1.5$ & $1.5-2.2$ \\
\hline
\end{tabular}

resolution DEM derived from the DGPS survey, as described in Hector et al. (2013).

\subsubsection{Vegetation}

Non-disturbed natural vegetation in this area is mostly woodland, composed of trees with a herbaceous layer underneath. Under human influences, trees are usually cut in favour of agricultural plots. However, trees in the riparian areas and the inland valley fringes are generally kept alive, as well as specific species on the hillslopes for consumption purposes (agroforestry system). This is why we consider in this study two vegetation classes: trees and herbaceous. While the trees class refers to a fully tree-covered state with some herbaceous layer underneath, the herbaceous cover refers to a mixed fallow-field landscape with sparse trees, composed of either cultivated plots or young fallows under the influence of farmers or with some isolated trees (with height $<10 \mathrm{~m}$ ) kept for local consumption.

Tree phenology mostly consists in defoliation around January, which occurs asynchronously between different species and different individuals of the same species (Seghieri et al., 2012). On the other hand, in the so-called herbaceous cover, the ground is commonly covered by scattered shrubs, while the actual herbaceous layer usually starts growing in April after the first rains and reaches its maximum height (up to $2.5 \mathrm{~m}$ ) in October. At this time its height exceeds that of shrubs. Then, the herbaceous layer stops transpiring and dries up from October to January. Controlled fire is a traditional practice in Benin; the vegetation (mainly the herbaceous layer) is burnt between November and February. Hence, during the dry season, the soil is bare for about 5 months. Leaf area index (LAI) and stem area index of trees and herbaceous classes are later shown in Fig. 6a.

\subsection{Critical zone model}

The CZ model ParFlow-CLM (PFCLM) is composed of ParFlow, a three-dimensional integrated physical model that simultaneously solves variably saturated flow and surface outflow coupled with CLM, a land surface model which solves both the water and energy budget at the surface. ParFlow uses a free-surface overland flow boundary condition which routes ponded water as overland flow using the kinematic wave equation and Manning equation (Kollet and
Maxwell, 2006). In this study, the topographic effect is taken into account by a terrain-following grid (Maxwell, 2013) and only requires two-dimensional surface slopes to be provided. ParFlow solves the Richards equation using cell-centered finite differences in space and an implicit backwards Euler scheme in time. The Newton-Krylov method is used together with a multigrid preconditioner and shows excellent parallel scaling, which allows the simulation of large-scale domains (i.e. continental US) at high resolution (i.e. $<1 \mathrm{~km}$ ) (Ashby and Falgout, 1996; Jones and Woodward, 2001; Maxwell et al., 2015). ParFlow is coupled through the user-defined $N$ first cells from the surface to a modified version of the Community Land Model (CLM) which solves both the water and energy budget at the surface (Dai et al., 2003; Maxwell and Miller, 2005). CLM has one vegetation layer and the version within ParFlow currently only allows a single vegetation class per surface grid cell. PFCLM is an excellent candidate for this study because it allows the representation of a number of physical processes that have been observed in Sudanian western Africa (perched water tables, groundwater and subsurface water baseflow, stormflow, plant transpiration and bare ground evaporation). This is achieved using physical parameters (hydrodynamic properties, vegetation parameters, complex three-dimensional lithological or pedological units) and without prior specification of the processes. The model has already been successfully applied in the region, using measured parameters for simulating vertical water fluxes (evapotranspiration, percolation) and specific features like perched water tables (Robert, 2012). We used the tagged version v3.3.1-IGE (https:/github.com/ basileh/parflow/releases/tag/v3.3.1-IGE, last access: 24 October 2018).

\subsection{Model set-up}

We model an idealized elementary headwater catchment, comprising an inland valley, of $720 \mathrm{~m} \times 300 \mathrm{~m}$ catchment $\left(0.216 \mathrm{~km}^{2}\right)$, with a $20 \mathrm{~m}$ lateral $(x, y)$ resolution (Fig. $1, \mathrm{Ta}-$ ble 2). The idealized inland valley and its contributive area have a V-shaped type (Maxwell et al., 2014), sloping in the $Y$ direction (Fig. 1a). The $Y$ direction slope is $4 \%$ and the $X$ direction slope is $2 \%$, following Runge (1991) and specific values for the Nalohou catchment. The cells in the centre represent the potentially overflowing section of the inland valley. 
Table 2. Model set-up

\begin{tabular}{ll}
\hline Property & Value \\
\hline Extension X & $300 \mathrm{~m}$ \\
Extension Y & $720 \mathrm{~m}$ \\
Extension Z & $10.5 \mathrm{~m}$ \\
DX (grid resolution) & $20 \mathrm{~m}$ \\
DY & $20 \mathrm{~m}$ \\
DZ & variable: $0.13-1.19 \mathrm{~m}$ \\
Duration & 8 years \\
Dt & $0.5 \mathrm{~h}$ \\
Slope X & $2 \%$ \\
Slope Y & $4 \%$ \\
\hline
\end{tabular}

Table 3. Hydrodynamic properties for the virtual V-shaped catchment, following Van Genuchten (1980).

\begin{tabular}{lrrrrr}
\hline & $\theta_{S}$ & $\theta_{r}$ & $\mathrm{Ks}_{\left(\mathrm{m} \mathrm{s}^{-1}\right)}$ & hg $(\mathrm{m})$ & $n$ \\
\hline H1 & 0.4 & 0.01 & $1.11 \times 10^{-4}$ & 0.3 & 1.8 \\
H2 & 0.36 & 0.01 & $2.8 \times 10^{-4}$ & 0.3 & 1.65 \\
H3 (clay) & 0.45 & 0.056 & $5.6 \times 10^{-9}$ & 1 & 1.3 \\
H3 (saprolite) & 0.3 & 0.004 & $1.10^{-5}$ & 1.3 & 1.76 \\
H3 (inland valley) & 0.3 & 0.004 & $2.8 .10^{-5}$ & 0.33 & 1.65 \\
\hline
\end{tabular}

These cells are further lowered by $2 \mathrm{~m}$ below the altitude of the inland valley fringes, to represent the classically observed banks.

The vertical resolution varies with depth following a geometric progression of common ratio 1.2 for the first 13 cells (which are coupled to CLM), ranging between 0.134 and $1.195 \mathrm{~m}$, and 4 more $1 \mathrm{~m}$ thick cells, uncoupled to CLM, are added at the bottom. The domain is therefore $10.5 \mathrm{~m}$ thick. Selected hydrodynamic parameters based on expertisedriven sensitivity studies within the range of observed values (Table 1) are shown in Table 3.

No-flow boundary conditions are applied to the catchment edges (symmetric assumption) and bottom. The only way for the water to leave the domain, apart from evapotranspiration, is through overland flow at the catchment outlet.

\subsection{Model forcings}

\subsubsection{Atmospheric forcing}

Forcing data are obtained from the Benin site of the AMMACATCH observatory (AMMA-CATCH, 1996) and are available on the data portal (http://db.amma-catch.org, last access: 24 October 2018). This meso-scale site comprises the Upper Ouémé catchment $\left(14300 \mathrm{~km}^{2}\right)$ which is representative of the Sudanian climate. The meteorological variables used to force CLM (wind speed, air temperature and humidity, pressure and the incoming radiative long and short waves, Fig. 2) were measured at a $2 \mathrm{~m}$ height on a flux tower located on a cultivated site (the Nalohou catchment, lat. $9.74^{\circ} \mathrm{N}$, long. $1.60^{\circ} \mathrm{E}, 449 \mathrm{~m}$ a.s.l.). Rainfall is measured with a tipping-bucket rain gauge.

Western African rainfall follows the monsoon dynamics and is characterized by a strong variability at interannual scales (see e.g. Lawin (2007) and Le Lay and Galle (2005) for detailed analyses of the Sudanian rainfall regime). In the simulated years, yearly precipitation amounts ranged from 913 to $1572 \mathrm{~mm}$ (Fig. 2).

Figure 2 shows the meteorological variables used to force PFCLM. They have been described in Mamadou et al. (2014) for the year 2008 and recently compared to data from a site $13 \mathrm{~km}$ away over a forested cover for the period 2008-2010 (Mamadou et al., 2016). The daily meteorological conditions of the two sites were expectedly close. Minimal values of incoming short-wave radiations $\left(\mathrm{SW}_{\text {in }}\right)$ are observed during the wet season due to cloud cover, and low values are also found at the core of the dry season, due to aerosols brought by the north-easterly Harmattan winds. Incoming long-wave radiations $\left(\mathrm{LW}_{\mathrm{in}}\right)$ are low during the dry season due to the reduced cloud cover. The highest air temperatures are observed before the start of the wet season, while the wet season exhibits the lowest daily average and amplitude of temperature. Specific humidity clearly shows the monsoon/Harmattan signal: during the wet season, moist air is brought by the southwesterly to southerly monsoon winds and during the dry season north-easterly Harmattan winds bring dry air from the Sahara. The Harmattan blows as a light to moderate breeze. These weather types are typical for Sudanian regions (Lohou et al., 2010; Sultan and Janicot, 2003).

PFCLM is forced at a $30 \mathrm{mn}$ time step, over the 7-year period 2006-2012, with spatially homogeneous forcings. Initial conditions are set as a water table depth of $3 \mathrm{~m}$, in accordance with several water table measurements. The model is spun up for 1 year, which corresponds to the year 2007, a rather average year.

\subsubsection{Vegetation forcings}

In this study, we forced the model with observation-based time series of LAI, SAI (stem area index), displacement heights and roughness lengths for the two vegetation classes of our domain (trees and herbaceous).

Vegetation height was monitored over a herbaceouscovered site (Nalohou) and a forest site $13 \mathrm{~km}$ away and further used to calibrate a simple API (Antecedent Precipitation Index)-like model which takes precipitation as input (Kohler and Linsley, 1951), and with the assumption that vegetation growth follows soil moisture availability. This allowed derivation of vegetation heights during the growing period at a daily time step for herbaceous cover for years where only precipitation data were available. Roughness lengths and displacement heights have been derived from these time series following the Brutsaert approach (Brutsaert, 1982) calibrated on in situ eddy covariance measurements. The LAI time series is a combination of satellite LAI products (CYCLOPE, 


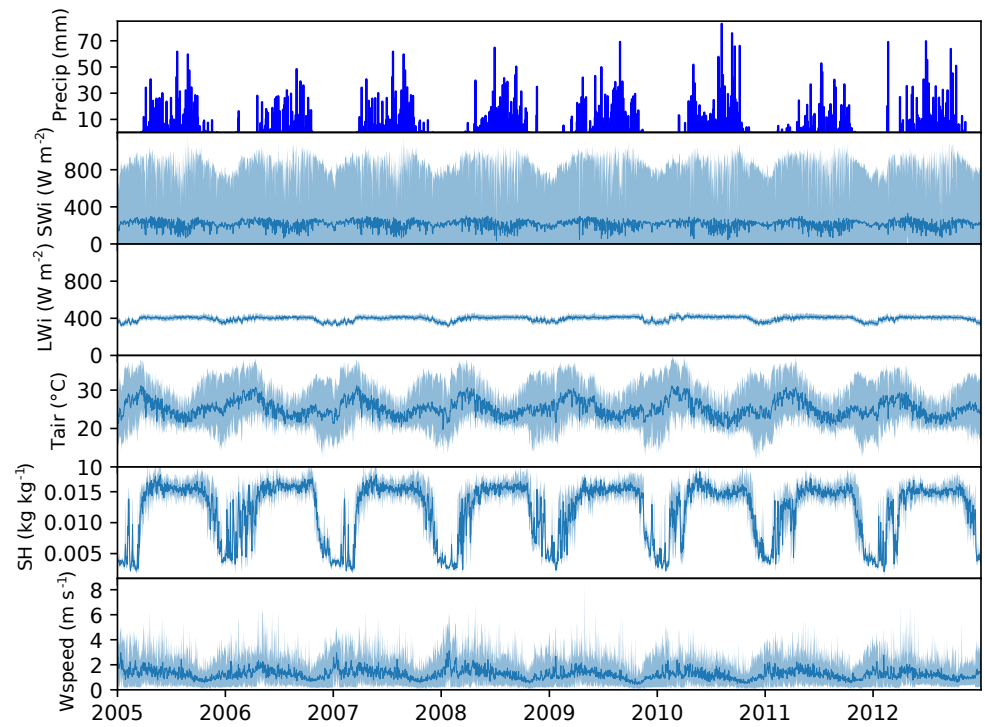

Figure 2. Model forcing. Upper panel: daily precipitation. $\mathrm{SW}_{\mathrm{in}}$ : incoming short waves, $\mathrm{LW}_{\text {in }}$ : incoming long waves, $T_{\mathrm{a}}$ : air temperature, SH: specific humidity, wind spd: wind speed. Data are shown as the daily mean (black curve) and daily minima and maxima (shaded area).

MODIS, SEVIRI), constrained by in situ measurements derived from hemispherical photographs based on the method proposed by Weiss et al. (2004), on both the forested and herbaceous-covered sites. Herbaceous SAI is also calculated from LAI using the equation $\left(\mathrm{LAI}+\mathrm{SAI}=\mathrm{LAI}_{\max }\right)$ during the senescence period (see the later Fig. 6a for the LAI and SAI time series used in the model forcing).

For the herbaceous cover, the root distribution in the model follows that of Zeng (2001), which is an exponential shape for the cumulative root fraction $(Y)$ to depth (d) of equation $Y=1-\frac{1}{2}\left(e^{-a \mathrm{~d}}+e^{-b \mathrm{~d}}\right)$, with the two coefficients $a=9$ and $b=2$. For the trees, the distribution is kept uniform over the first $3 \mathrm{~m}$ below the surface, because we found the Zeng equation not relevant for most Sudanian trees for which efficient deep roots have been observed (Jourdan, Gnanglé, Seghieri and Peugeot, personal communication). The closest published study on deep roots in natural forest is in a slightly different setting in tropical semi-deciduous rain forest where $95 \%$ of all roots from E. cylindricum were distributed to depths of between 2.58 and $5.64 \mathrm{~m}$ (Freycon et al., 2015).

\subsection{Evaluation data}

As a first step, we evaluate the relevance of the model with respect to real-world data (water table depth measurements, soil moisture, streamflow records, evapotranspiration and gravity data). This section describes the evaluation data obtained from the Nalohou catchment, whose size and structure are comparable to that of our virtual V-shaped catchment (Fig. 1a). The Nalohou catchment comprises a small inland valley and is considered to be representative of a cultivated site. It has been the focus of previous studies (De- scloitres et al., 2011; Guyot et al., 2012; Hector et al., 2015; Richard et al., 2013). Land surface elevation ranges from 436 to 460 m.a.s.l., and topographic slopes are gentle (mean N-S and E-W slopes correspond to those imposed on the virtual V-shaped catchment).

Observations in P1 and P2 (Fig. 1a) were used to evaluate the simulated groundwater dynamics. At the inland valley location in P1 there is a shallow, $1 \mathrm{~m}$ deep piezometer which aims at documenting the seasonal perched water table and a deeper $(10 \mathrm{~m})$ piezometer monitoring the permanent water table.

Streamflow measurements have been described in AMMA-CATCH (2008). A Parshall flume was built in 2004 at the outlet of the inland valley (Q2 in Fig. 1a) and recorded any level change above $10^{-3} \mathrm{~m}$, using a level probe (OTT Thalimedes).

Two eddy covariance flux towers have been installed, respectively, on the Nalohou site (where the flux tower footprint is representative of cultivated, herbaceous-like areas) and on the woodland site (Mamadou et al., 2016). Furthermore, an infrared large-aperture scintillometer (LAS) was deployed from 2006 to 2008 on the Nalohou site (Guyot et al., 2009, 2012). LAS measurements give access to an average sensible heat flux over the footprint area and, by closing the energy budget, this allows us to derive the average latent heat flux (i.e. evapotranspiration). On the Nalohou site, the beam path was $2.4 \mathrm{~km}$ long, and comprised many more trees than in the flux tower footprint area.

Time-domain reflectometry (TDR) probes have been set up on the eastern bank of the Nalohou catchment at about $150 \mathrm{~m}$ eastward of latitude point $Y=300 \mathrm{~m}$ of Fig. 1a. Soil 
moisture content is derived from the measurements at a hourly time step (AMMA-CATCH, 2005b).

Gravity instrumentation originates from the GHYRAF (Gravity and Hydrology in Africa) project, which sought to study gravity to water storage change (WSC) relationships (Hinderer et al., 2009, 2012). Gravity instruments were an absolute (AG hereafter) FG5 gravimeter (Hector et al., 2013), a relative superconducting gravimeter (Hector et al., 2014, SG hereafter) and a CG5 relative portable spring gravimeter (Hector et al., 2015). Relative spring microgravimeters measure differences in gravity between stations, while other instruments such as SG or AG measure changes at a specific site. Hybrid gravimetry is the joint use of gravity surveys using relative microgravimeters and monitoring of temporal changes at a base station, using an SG and/or AG (Hinderer et al., 2016). From the hybrid gravity data set of Nalohou, Hector et al. (2015) produced a map of the seasonal amplitude of gravity changes (their Fig. 11). In this study, we convert gravity changes to water storage changes using a simple scalar admittance (gravity changes to WSC ratio) of $0.04 \mu \mathrm{Gal} \mathrm{mm}^{-1}$, in accordance with local topography, and following the admittance calculated by Hector et al. (2015).

\subsection{Analysis tools}

WSC analysis is conducted using empirical orthogonal function (EOF) decomposition. EOF decompositions can be seen as principal component analysis applied to the time series of a spatial field. The method produces spatial patterns of variability (in terms of variance), their associated time variation together with a measure of the weight (importance) of each pattern (in terms of explained variance). In other words, the whole data set of coordinates $(x, y, t)$ is decomposed into the weighted sum of modes, where each mode is the product of an EOF spatial pattern (an $(x, y)$ map) with a normalized time series. The weights are given in terms of how much of the total signal variance is contained in the associated mode. This method has been used on WSCs from hybrid gravity data and neutron probe data at the Nalohou catchment size by Hector et al. (2015), who showed that the first mode could be interpreted as the seasonal signal.

To measure the goodness-of-fit between simulations and observations, we use the Kling-Gupta efficiency (KGE) criterion (Gupta et al., 2009):

$\mathrm{KGE}=1-\sqrt{(r-1)^{2}+(\alpha-1)^{2}+(\beta-1)^{2}}$,

where $r$ is the linear correlation coefficient between simulated and observed time series and

$\alpha=\frac{\sigma_{\mathrm{S}}}{\sigma_{\mathrm{O}}} ; \beta=\frac{\mu_{\mathrm{S}}}{\mu_{\mathrm{O}}}$,

and $\left(\mu_{\mathrm{S}}, \sigma_{\mathrm{S}}\right)$ and $\left(\mu_{\mathrm{O}}, \sigma_{\mathrm{O}}\right)$ are the mean and SD of, respectively, simulated and observed time series. KGE has an ideal value at unity.

\subsection{Overview of the three virtual experiments}

We model an elementary headwater catchment and test its sensitivity to (1) the presence of a low-permeability layer underneath an inland valley, (2) the vegetation distribution, and (3) the hydrodynamic properties of contributive areas ( $\mathrm{H} 3$ layer). To do so, we build a set of virtual experiments that are compared to a benchmark simulation (named the "reference" case hereinafter, Table 4). This reference simulation includes an inland valley characterized by an impervious layer made up of a clay lens underlying an upper sandy layer in the valley thalweg. Vegetation distribution and H3 layer are both chosen arbitrarily in this simulation. An anthropized vegetation distribution (mostly herbaceous but also with trees in the riparian areas) allows comparison of model outputs with observed hydrological variables at the Nalohou catchment. A clay-like contributive area (H3 outside the inland valley cells) is chosen between the two main pedological features (clay and saprolite). The three virtual experiments are as follows (Table 4).

The first experiment explores the impacts of the lowpermeability layer in the valley thalweg on the hydrological functioning of the catchment. This experiment consists in removing the impervious layer below the $\mathrm{H} 2$ horizon (upper part of $\mathrm{H} 3$ as shown in Fig. 1b) in the valley thalweg with respect to the reference case. Other parameters (hydrodynamic, vegetation) are kept identical.

The second experiment explores the impact of the vegetation cover with three cases: the "natural" state where the catchment is fully covered with trees, and the "anthropized" state with two different vegetation covers: (1) either the catchment is covered with grass, except in the riparian and inland valley fringe areas where trees remain (as in Fig. 1athis is the reference case), or (2) the catchment is fully covered with grass (no trees).

In the third experiment, we test three different configurations for the $\mathrm{H} 3$ layer outside the valley thalweg, with $\mathrm{H} 1$ and $\mathrm{H} 2$ left unchanged, as the contributive area within $\mathrm{H} 3$ drives the subsurface and groundwater transfer toward the inland valley. The reference case considers clay material only in the H3 layer, and the two other cases consider, respectively, (1) a sandy to loamy saprolite in the H3 layer and (2) a clay zone on the western side of the virtual catchment and a sandy zone on the eastern side (asymmetric case), both above the hardrock considered to be impervious. These configurations are based on two distinct soil profiles commonly found in the Sudanian landscape (Faure and Volkoff, 1998). 
Table 4. Virtual experiments. "Trees and herbaceous" refers to trees only in riparian areas and inland valley fringes, as shown in Fig. 1.

\begin{tabular}{|c|c|c|c|}
\hline & $\begin{array}{l}\text { Clay lens in } \\
\text { the valley thalweg }\end{array}$ & H3 layer & Vegetation \\
\hline Reference case & yes & Clay & Trees and herbaceous \\
\hline Exp. 1: inland valley & no & Clay & Trees and herbaceous \\
\hline \multirow[t]{2}{*}{ Exp. 2: vegetation } & \multirow[t]{2}{*}{ yes } & \multirow[t]{2}{*}{ Clay } & Trees only \\
\hline & & & Herbaceous only \\
\hline \multirow[t]{2}{*}{ Exp. 3: contributive areas } & \multirow[t]{2}{*}{ yes } & Saprolite & \multirow[t]{2}{*}{ Trees and herbaceous } \\
\hline & & $\begin{array}{l}\text { Clay in the west, } \\
\text { saprolite in the east }\end{array}$ & \\
\hline
\end{tabular}

\section{Results}

\subsection{Reference case and saprolite case compared to Nalohou observations}

\subsubsection{Water storage changes}

Water storage changes (WSCs) are shown in Fig. 3 as the spatial and temporal patterns of the first mode of the EOF decomposition. While the left panel shows the simulated WSCs, the right panel shows WSCs obtained from the hybrid gravity data by interpolation from point-based values (blue dots). The first mode of the simulated WSCs represents more than $90 \%$ of the variance. This means that more than $90 \%$ of the total signal variance is contained in the first EOF spatial pattern multiplied by its associated time series (Fig. 3c, red line). The time series shows that this mode corresponds to the seasonal cycle (the common part of the signal which explains most of the total variance). In that sense, we can directly interpret the spatial patterns (i.e. the EOFs) as maps of seasonal water storage amplitudes. The first mode of gravity-derived WSCs also explains a significant part (79\%) of the total variance. As this map derives from an interpolated field, and although gravity data are spatially integrative, observed geometries should not be overinterpreted. Mode 2 (not shown) accounts for about $8 \%$ of the total variance, and contains interannual storage variations together with some residuals at the seasonal level.

The reference simulation includes an inland valley (a lowpermeability layer in the upper part of the $\mathrm{H} 3$ horizon) and the clayey material in the H3 layer outside the inland valley corresponds to what is found on the western bank of the Nalohou catchment. In this regard, the simulated spatial pattern matches two important features of the observations: a high amplitude in the inland valley and a low amplitude in the clayey area. The high simulated amplitude in the downstream section (500 to $700 \mathrm{~m}$ ) is due to tree withdrawals during the dry season. Gravity data do not cover this part of the catchment, which prevents the comparison with the sim-
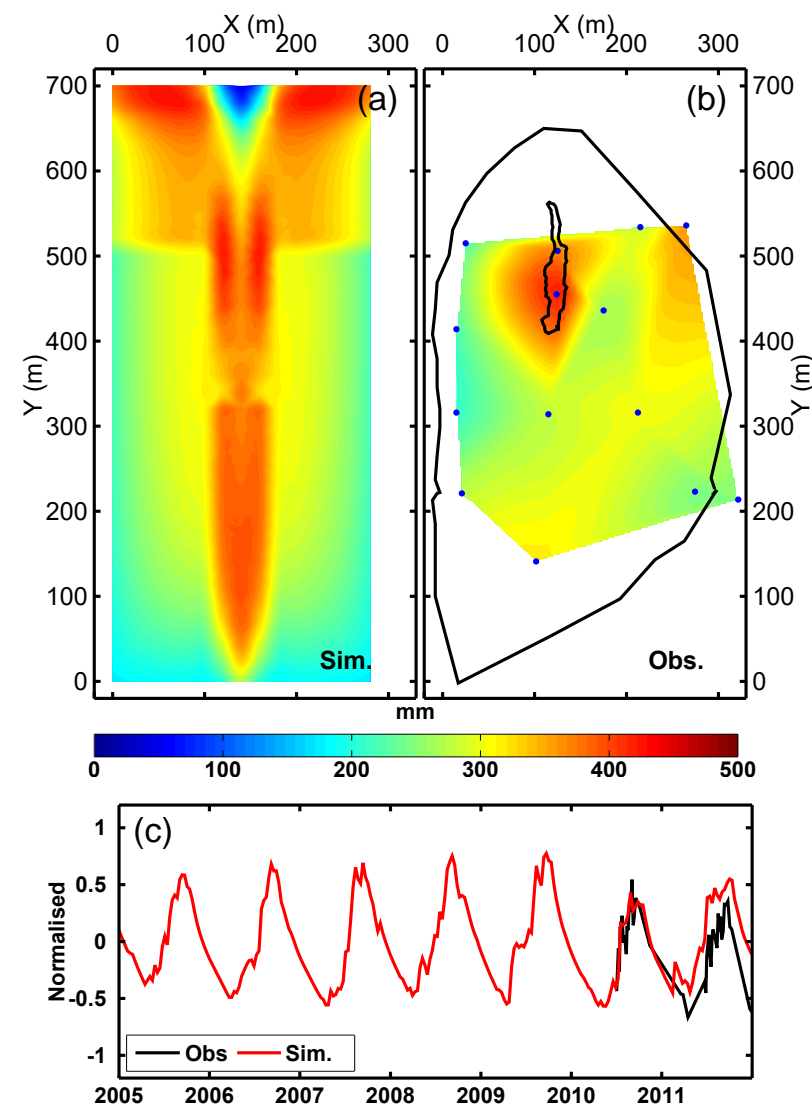

Figure 3. Empirical orthogonal function decomposition of water storage changes (WSC). (a, b) Spatial patterns of WSC for the first mode of EOF. (a) Simulated WSC and (b) observed, gravity-derived WSC at the Nalohou catchment (blue points are station locations). The outline of the inland valley is shown for the Nalohou catchment. (c) Temporal pattern of the first mode of simulated and observed WSC.

ulated data. The low amplitude on the sides of the catchment is due to the impermeable clay in the $\mathrm{H} 3$ horizon, which prevents water from percolating downward and favours lateral 
transfer to the valley thalweg where water accumulates during the wet season, and drains down toward the riparian areas during the dry season. High amplitude is simulated along the whole valley thalweg and not only in the inland valley, as the observation shows.

\subsubsection{Water table}

Figure 4a shows simulated time series of saturation profiles at $\mathrm{P} 1$, in the inland valley for the reference simulation. Red lines show the simulated water tables, while white lines show the observed water tables. The model is able to reproduce seasonal fluctuations of both the permanent water table and the temporary perched water table. Although numerous discrepancies exist (e.g. the seasonal amplitudes of the permanent water table), mainly because of the horizontal and vertical variability of hydrodynamic parameters which have been considered constant in layer H3, the first order of this complex behaviour is reproduced. In particular, the interannual behaviour of the permanent water table is rather satisfying, despite a slight phase shift, but higher-frequency responses of the shallow perched water table at the core of the rainy season are also well reproduced.

Figure $4 \mathrm{~b}$ shows simulated time series of saturation profiles at P2, in the upstream area for the saprolite simulation (sandy H3 layer everywhere but in the inland valley). This sandy $\mathrm{H} 3$ layer is a common feature of the environment, particularly on the eastern bank of the Nalohou catchment. The simulated permanent water table matches satisfyingly the observation representative of this sandy $\mathrm{H} 3$ unit.

\subsubsection{Streamflow}

Figure 5 shows simulated and observed streamflow expressed in $\mathrm{mm} \mathrm{h}^{-1}$, which allows the comparison between the Nalohou catchment $\left(0.16 \mathrm{~km}^{2}\right)$ and the $\mathrm{V}$-shaped model $\left(0.22 \mathrm{~km}^{2}\right)$. We chose to focus the plot on the baseflow part of the time series, cutting the highest flow peaks, for two reasons: (1) Hector et al. (2015) noted that in such settings baseflow is the major contributor to total measured streamflow (about 80\%) and (2) the following sections will present semilog plots of the different experiments simulated, which allow us to display the whole range of streamflow values but with less intuitive interpretation. Overall, the match is satisfying, and the simulation respects baseflow onset and recession behaviours. The only negative KGE value for the year 2009 composed of ( $r=0.96, \alpha=1.56, \beta=1.84)$ is mostly explained by a high bias and overly high simulated variance, while the time phasing matches well. It has to be noted that the simulation produces higher flow peaks than observed for some events, but not all (see further Fig. 9). Discrepancies between observed and simulated streamflow are higher in drier years (i.e. 2011). This is due to the complexity of connectivity between different contributive compartments, which is over-simplified in our idealized simula-

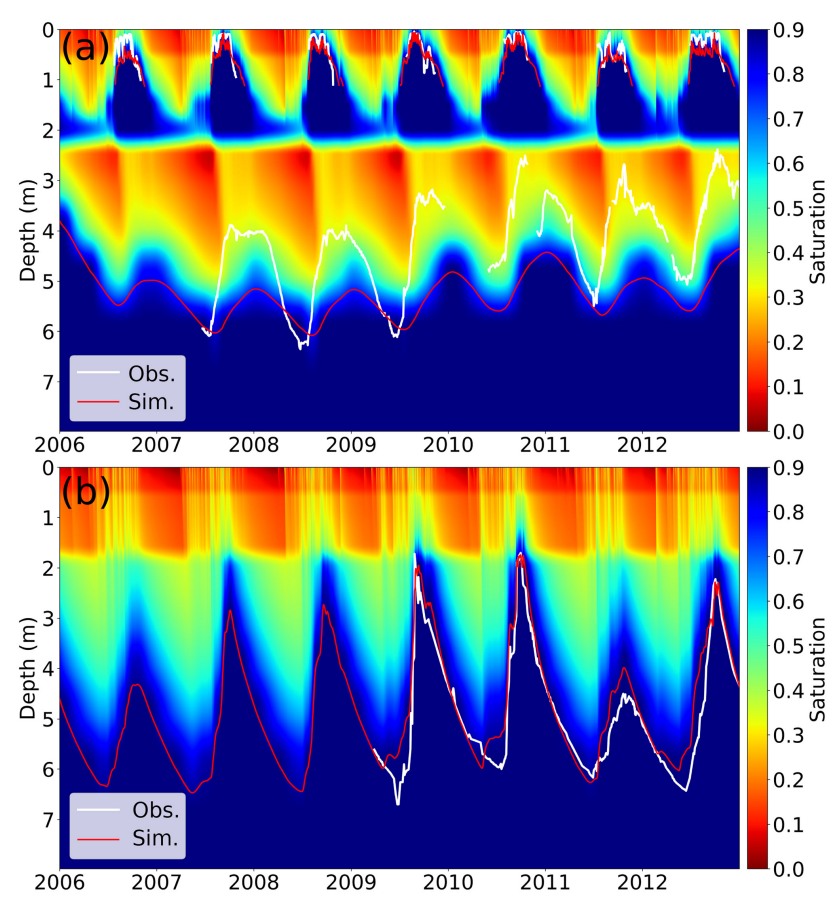

Figure 4. Simulated saturation and observed and simulated water table. (a) In the inland valley (at P1) and for the reference simulation (clayey H3 layer); (b) in the upstream area (at P2) and for the saprolite simulation (sandy H3 layer).

tion. The simulated diurnal cycle in the ponded water (from which streamflow is calculated) is a model artifact due to the ponded cell size ( $20 \mathrm{~m}$ wide here).

\subsubsection{Evapotranspiration}

Figure 6a shows the LAI and SAI forcing time series used in this study for the two vegetation covers. Figure 6b (or Fig. 6d) shows the simulated daily evapotranspiration spatially averaged over herbaceous-covered cells out of the thalweg in light blue line for the reference simulation (or the saprolite simulation). The shaded area gives the whole spatial range of daily values between minimal (lower black line) and maximal (upper black line) spatial evapotranspiration. Figure 6c (or Fig. 6e) is similar, but for tree-covered cells. Reference (clay in the H3 unit everywhere but below the inland valley) and saprolite simulations are compared because the Nalohou flux tower is located on a saprolite-like material. The saprolite simulation actually matches more closely the observed evapotranspiration in the dry season.

During the dry season, trees renew their leaves and show a low LAI and limited evapotranspiration. The herbaceous cover have been burnt, and only some scattered shrubs and trees imply a non-zero LAI and little evapotranspiration. During the transition period between dry and wet seasons, tree LAI increases, herbaceous grows and evapotranspiration increases with both soil moisture (not shown) and plant abil- 


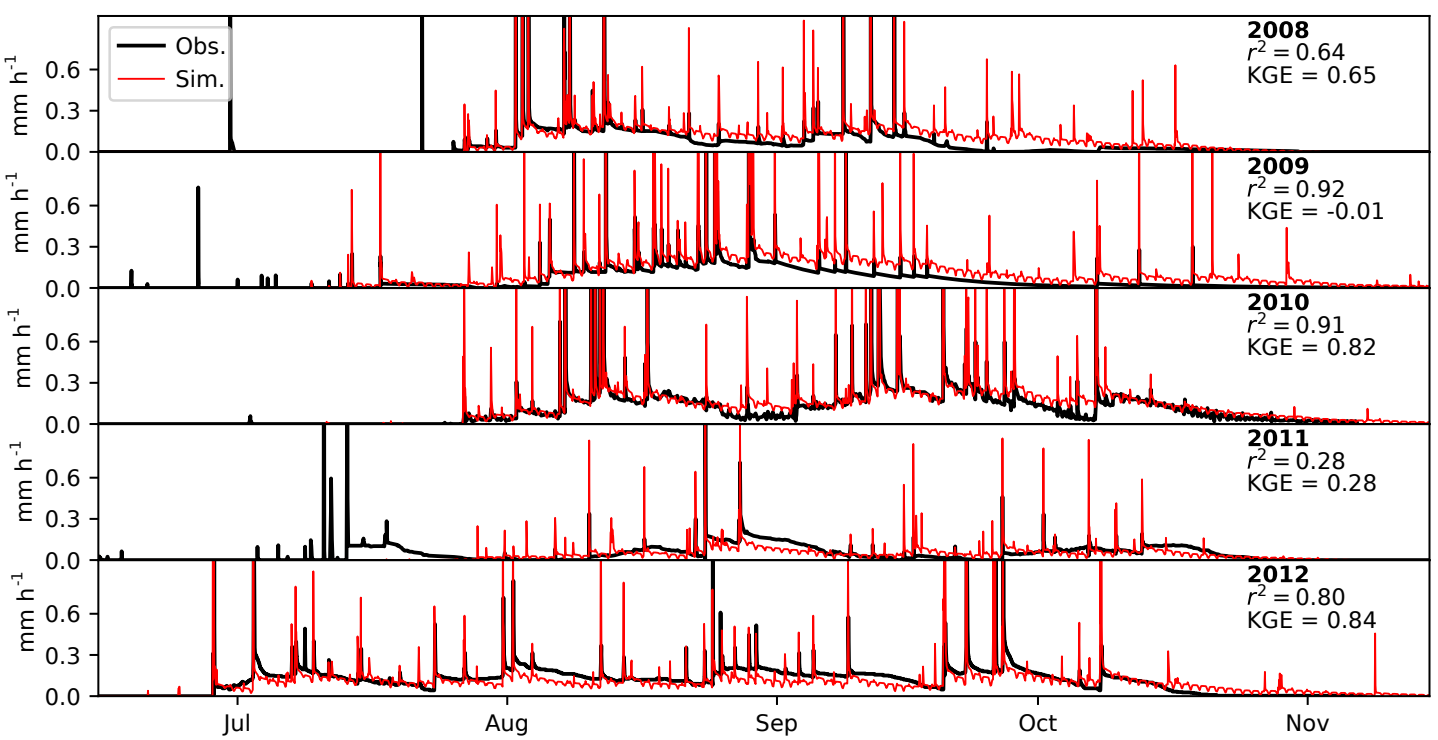

Figure 5. Observed and simulated streamflow for the wet seasons of the period 2008 to 2012 at station Q2.

ity to transpire with a higher LAI. During the wet season, the evapotranspiration is never water limited (Mamadou et al., 2016). During the transition period between wet and dry seasons, the herbaceous layer dries up, and LAI is replaced by SAI, which diminishes drastically the evapotranspiration. Herbaceous are eventually burnt at the end of this transition period (SAI drop in Fig. 6a), while trees start renewing their leaves.

Overall, the spatially averaged simulated evapotranspiration matches the observations, over both herbaceous and tree covers. At the end of the wet season, the simulated evapotranspiration (dominated by transpiration) is a little higher than the EC observations, but not higher than the LAS observations in 2008. EC is known to underestimate evapotranspiration (Foken, 2008).

\subsubsection{Soil moisture}

Because soil moisture probes are located on the eastern side of the Nalohou catchment, observed soil moisture is here compared to the "saprolite" simulation where $\mathrm{H} 3$ outside the inland valley is composed of sandy-like saprolite (Fig. 7). Simulations match the observed temporal patterns in a satisfying way, including recession behaviours.

\subsubsection{Annual water budget}

The water budget simulated for the reference case is shown in Table 5. As expected, evapotranspiration dominates the water budget (from $58 \%$ to $83 \%$ of the yearly precipitation amount) but shows a marked interannual variability as simulated in the area at basin scale (Cornelissen et al., 2013; Séguis et al., 2011) and from a review of different other spatial scales (Hector, 2014). For dry years, the ET part (or the $Q$ part) of the budget is higher (or lower) than for wet years. Interannual water storage changes are rather limited and do not seem to exhibit memory effects. In other words, the relative part of $(\mathrm{ET}+Q)$ in the water budget is stable over years. If we now consider the absolute values of the water balance terms, the difference between a wet year (2010) and the following dry year (2011) is $593 \mathrm{~mm}$ in rainfall, $135 \mathrm{~mm}$ in evapotranspiration, $420 \mathrm{~mm}$ in streamflow and $38 \mathrm{~mm}$ in water storage. Streamflow is the most affected term in a dry year: it undergoes a drastic loss of water, about 3 times greater than that of evapotranspiration, almost equal to its interannual average (454 mm). This results in the interannual SD of $Q$ being more than twice as large as the standard deviation of ET: the interannual variability in precipitation $(\mathrm{SD}=225 \mathrm{~mm}$ ) is mostly compensated by streamflow $(151 \mathrm{~mm})$ and to a lesser extent by evapotranspiration $(64 \mathrm{~mm})$ and water storage changes (26 mm).

\subsection{Virtual experiments}

\subsubsection{Annual water budgets}

The most important variations in yearly water budgets occur when comparing a tree-covered catchment and a herbaceouscovered catchment (Table 6). Mean interannual evapotranspiration is higher (or lower) and streamflow is lower (or higher) for the trees (or herbaceous)-covered catchment, while the reference case shows a somewhat intermediate behaviour. Interannual variability (i.e. as shown by the SD) is lower for the trees than for the herbaceous cover. Unlike other cases, interannual water storage changes may become significant in the tree-covered experiment, with a net decrease in water storage 


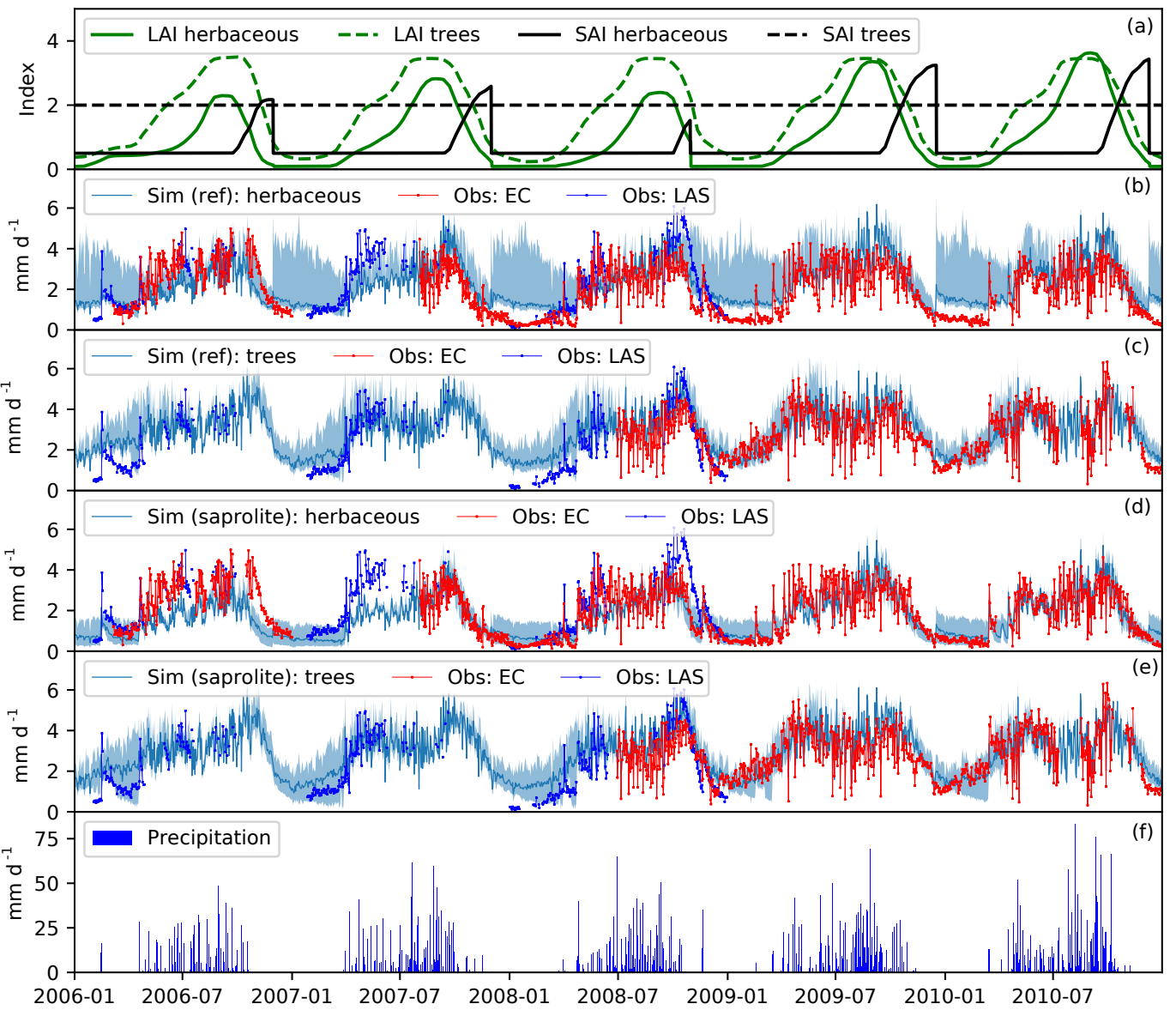

Figure 6. (a) LAI and SAI forcings for tree and herbaceous covers. (b-e) Observed and simulated evapotranspiration over herbaceous cells (b) and tree cells (c) for the reference simulation and the saprolite simulation (d and e). Blue line shows the spatial average over all cells of the respective cover out of the inland valley, and the shaded area shows the extent of spatial maxima and minima. (f) Precipitation.

Table 5. Water budgets for the reference case. Mean and SDs are calculated on the period 2007-2012.

\begin{tabular}{lrrrr}
\hline Year & $P(\mathrm{~mm})(\%)$ & ET $(\mathrm{mm})(\%)$ & $Q(\mathrm{~mm})(\%)$ & $S(\mathrm{~mm})(\%)$ \\
\hline 2006 & $913(100)$ & $775(85)$ & $197(22)$ & $-59(-6)$ \\
2007 & $1214(100)$ & $829(68)$ & $374(31)$ & $11(1)$ \\
2008 & $1211(100)$ & $799(66)$ & $400(33)$ & $12(1)$ \\
2009 & $1496(100)$ & $931(62)$ & $551(37)$ & $14(1)$ \\
2010 & $1527(100)$ & $881(58)$ & $644(42)$ & $3(0)$ \\
2011 & $934(100)$ & $746(80)$ & $224(24)$ & $-35(-4)$ \\
2012 & $1423(100)$ & $848(60)$ & $529(37)$ & $45(3)$ \\
Mean \pm SD (2007-2012) & $1301 \pm 225$ & $839 \pm 64$ & $454 \pm 151$ & $8 \pm 26$ \\
\hline
\end{tabular}

during the dry years. This results in a higher interannual SD of the storage term.

The presence of the impermeable layer (in the reference case) has very little effect on the water budget, lowering the streamflow by $2 \%(9 \mathrm{~mm})$ on average, in favour of evapotranspiration, with respect to the case without the impermeable layer.
The reference case (clayey) evapotranspirates slightly more than the saprolite-like case, $5 \%$ on average, while the mixed simulation (clayey left bank, saprolite right bank) shows an intermediate behaviour. 


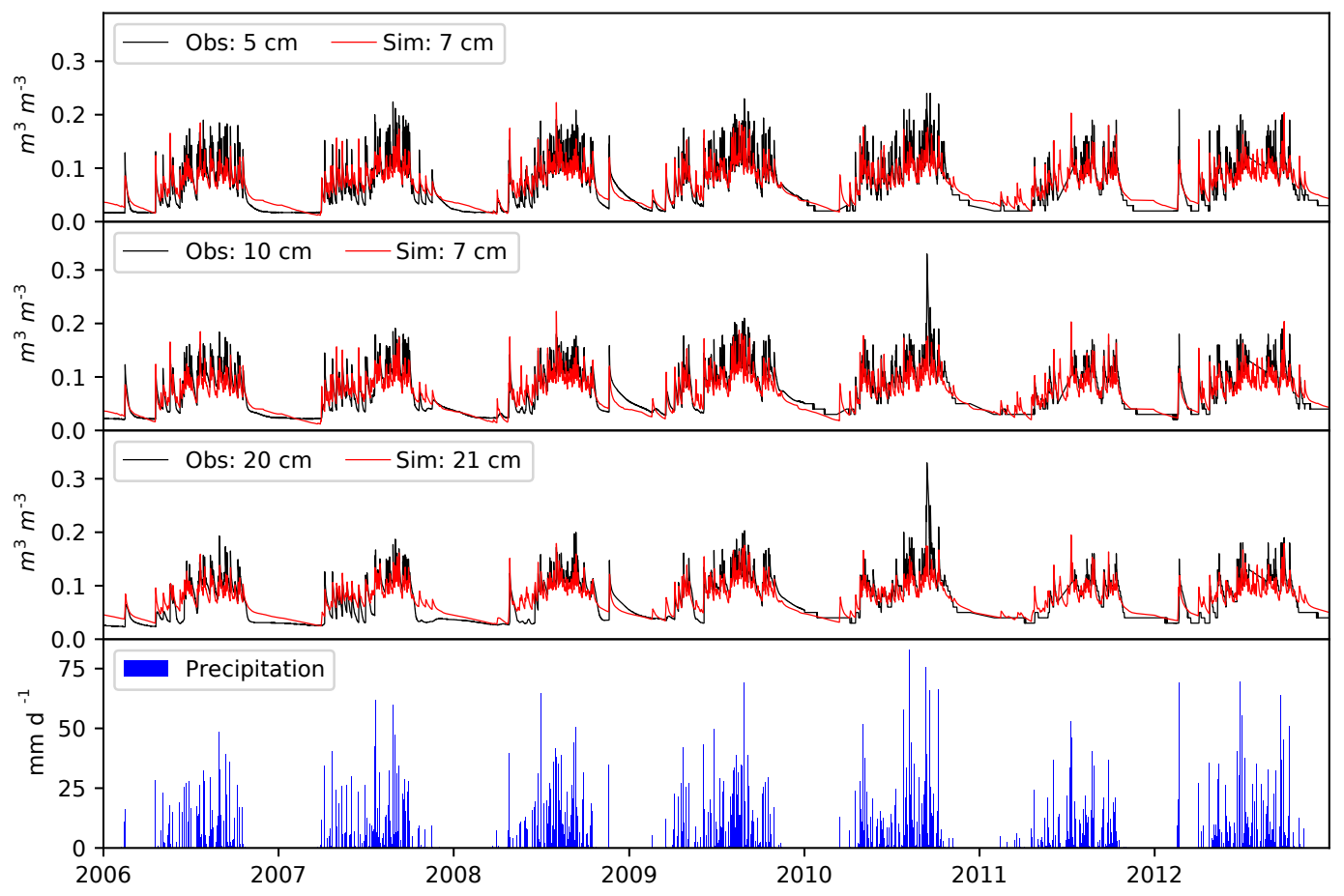

Figure 7. Observed and simulated soil moisture for the saprolite simulation at location P2.

Table 6. Interannual mean and SD of simulated evapotranspiration (ET), streamflow $(Q)$ and storage $(S)$ for the different virtual experiments and for the period 2007-2012.

\begin{tabular}{lrrr}
\hline & ET $(\mathrm{mm})$ & $Q(\mathrm{~mm})$ & $S(\mathrm{~mm})$ \\
\hline Reference & $839 \pm 64$ & $454 \pm 151$ & $8 \pm 26$ \\
No inland valley & $830 \pm 64$ & $463 \pm 153$ & $8 \pm 24$ \\
Trees & $944 \pm 53$ & $361 \pm 144$ & $-5 \pm 54$ \\
Herb & $791 \pm 72$ & $500 \pm 151$ & $10 \pm 17$ \\
Saprolite & $793 \pm 60$ & $495 \pm 153$ & $13 \pm 36$ \\
Mixed & $816 \pm 62$ & $475 \pm 154$ & $10 \pm 28$ \\
Slope ref $\times 0.5$ & $933 \pm 62$ & $354 \pm 154$ & $14 \pm 28$ \\
Slope ref $\times 2$ & $773 \pm 64$ & $526 \pm 157$ & $1 \pm 21$ \\
\hline
\end{tabular}

\subsubsection{Water storage}

Figure 8 shows water storage changes as the first modes of the EOF decompositions for all tested cases. In all cases, the first mode represents more than $90 \%$ of the variance.

The most striking discrepancies arise when comparing the results related to the contributive area experiments (Fig. 8a, e, f). While the reference case (clayey H3 layer, Fig. 8a) shows low seasonal amplitude in the valley banks and higher amplitude along the valley axis including the inland valley, the saprolite case (Fig. 8e) shows a rather opposite behaviour with higher amplitude on the banks and lower amplitude in the valley axis. In the reference case, the southern, upstream edge of the inland valley exhibits a break in the seasonal amplitude, while this is not visible in the saprolite case (in this case there is no specific imprint of the inland valley). In the mixed case (Fig. 8f), the southern, upstream edge of the inland valley also exhibits a different seasonal amplitude, but of opposite behaviour, as in the reference case.

In the vegetation experiment (Fig. 8a, c, d), the treecovered catchment (Fig. 8c) shows higher seasonal amplitude than the herbaceous-covered catchment (Fig. 8d), while the reference case shows patterns closer to the herbaceouscovered catchment. In the time series, seasonal WSC increase occurs earlier on herbaceous cover than on trees.

The absence of the impermeable layer in the inland valley increases the seasonal water storage amplitude along the thalweg (Fig. 8b).

In all cases, there is low seasonal amplitude at the catchment outlet (the northern blue patch). This is the imprint of the topography (all cells converge to that point) and the model boundary condition: the only way for the water to exit the domain, apart from evapotranspiration, is through this outlet.

The mixed simulation characteristics are actually the closest to the conceptual model presented by Hector et al. (2015). And the observed spatial pattern (Fig. 2) matches several features of the mixed simulation: a high amplitude in the inland valley, a low amplitude on the clayey, left bank, area, and some intermediate amplitude in the saprolite-like right bank area. While this is satisfying, it has to be noted that the conceptual model proposed by Hector et al. (2015) lacks some details. In the mixed simulation (which follow their descrip- 
tive model), while streamflow, evapotranspiration and spatial pattern of WSC are well reproduced, the simulated permanent water table completely fills up the inland valley due to high permeability in the $\mathrm{H} 3$ layer on the right bank (see further), which is not observed. Hence there must be some barrier to the lateral flow feeding the inland valley. However, it would be interesting to investigate the existence of other inland valleys which do not show such disconnexion between the upper perched water table and lower permanent water table. Our study would anticipate that, all scaling issues discarded, such an inland valley would produce a similar water budget.

\subsubsection{Streamflow}

Yearly simulated streamflow time series (sampled on cell Q1, Fig. 1) are shown in Fig. 9 for the year 2011 and as semilog plots, with the reference time series repeated in all plots in black. Overall, streamflow simulations are rather similar. Many of the differences among the cases are related to the first part of the rainy season, in the timing of the streamflow onset and the streamflow amplitude during this period (this is also true for other years, not shown). Differences in the dry season are very low in terms of water amount (cf. the log scale), but exhibit clearly different behaviours: some cases are able to sustain a low baseflow during the dry season, while some others, including the reference case, prevent water flow during the dry season.

The presence of the impermeable layer in the inland valley (reference case) induces a higher streamflow in August (Fig. 9a). On the other hand, the absence of the impermeable layer favours infiltration and maintains a low baseflow longer in the dry season, fed by the permanent water table which is then connected all across the catchment.

The tree-covered catchment (Fig. 9b) tends to exhibit lower streamflow in August. The storm peaks are much attenuated, as compared to the reference case. The herbaceouscovered catchment shows a higher streamflow in the dry season and the early wet season, with slightly higher storm peaks than in the reference case. One may note how the reference $Q$ follows the trees $Q$ in the early season before August and then migrates to meet the herbaceous $Q$ that it follows until the reverse migration is observed in November. This likely denotes the course of the contributive area extension through the season, trees being only in the downstream section in the reference case.

The simulation with a saprolite-like contributive area (Fig. 9c) shows a higher dry season and early wet season streamflow as compared to the reference case and the mixed case. At the core of the rainy season, in August-September, the saprolite simulation shows a lower streamflow.
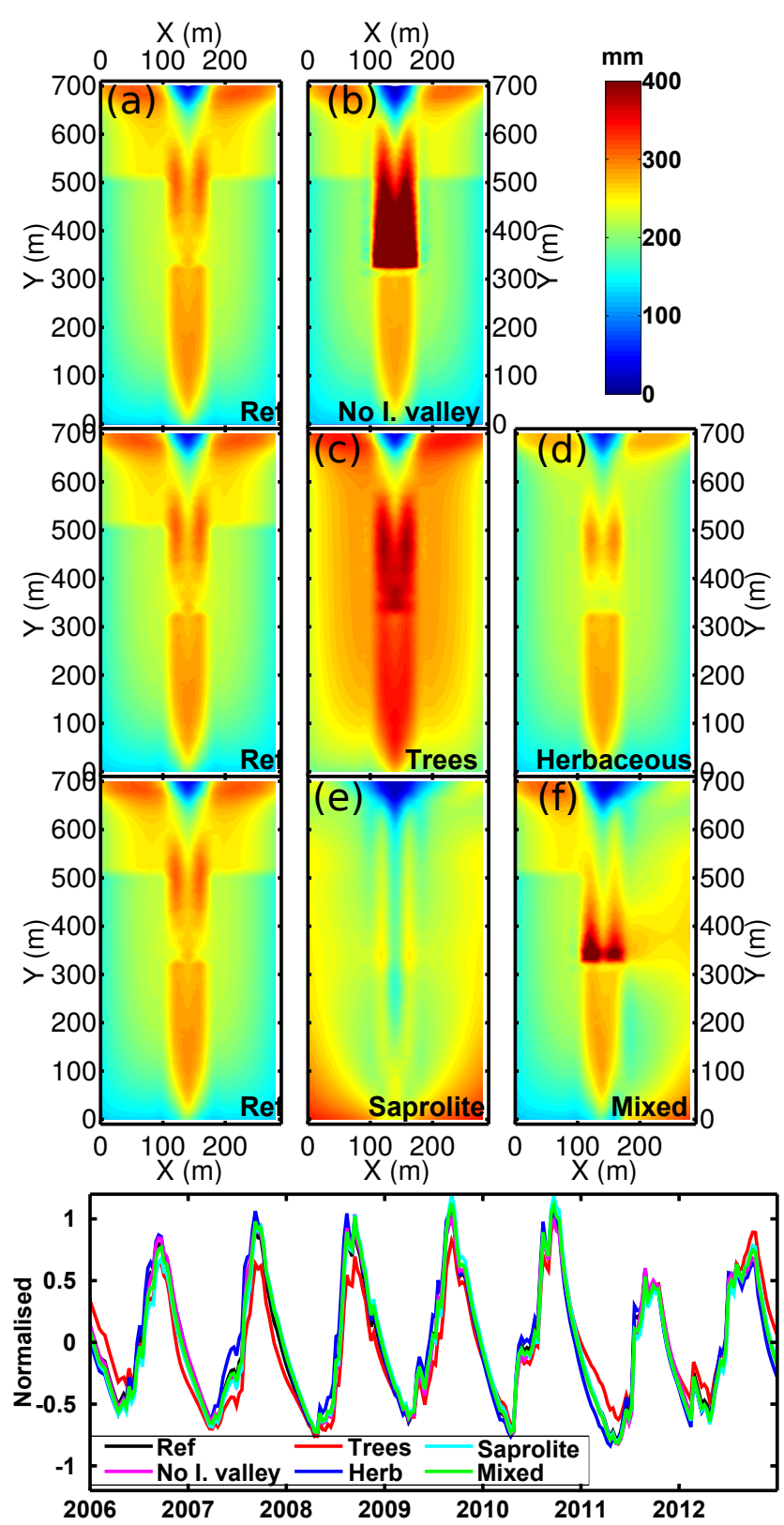

Figure 8. Simulated water storage changes: first mode of the EOF for all cases: upper panel: spatial patterns. Lower panel: temporal patterns.

\subsubsection{Water table}

Figure 10 shows the simulated water tables at two locations, in the inland valley (P1, Fig. 1), and in the upstream contributive area (P2, Fig. 1). When present, perched water tables are shown too.

As expected, the presence of the impermeable layer (Fig. 10a, as in the reference case) creates two water tables: a deep permanent, low-amplitude, water table and a shallow seasonal water table within the sandy layer of the inland val- 


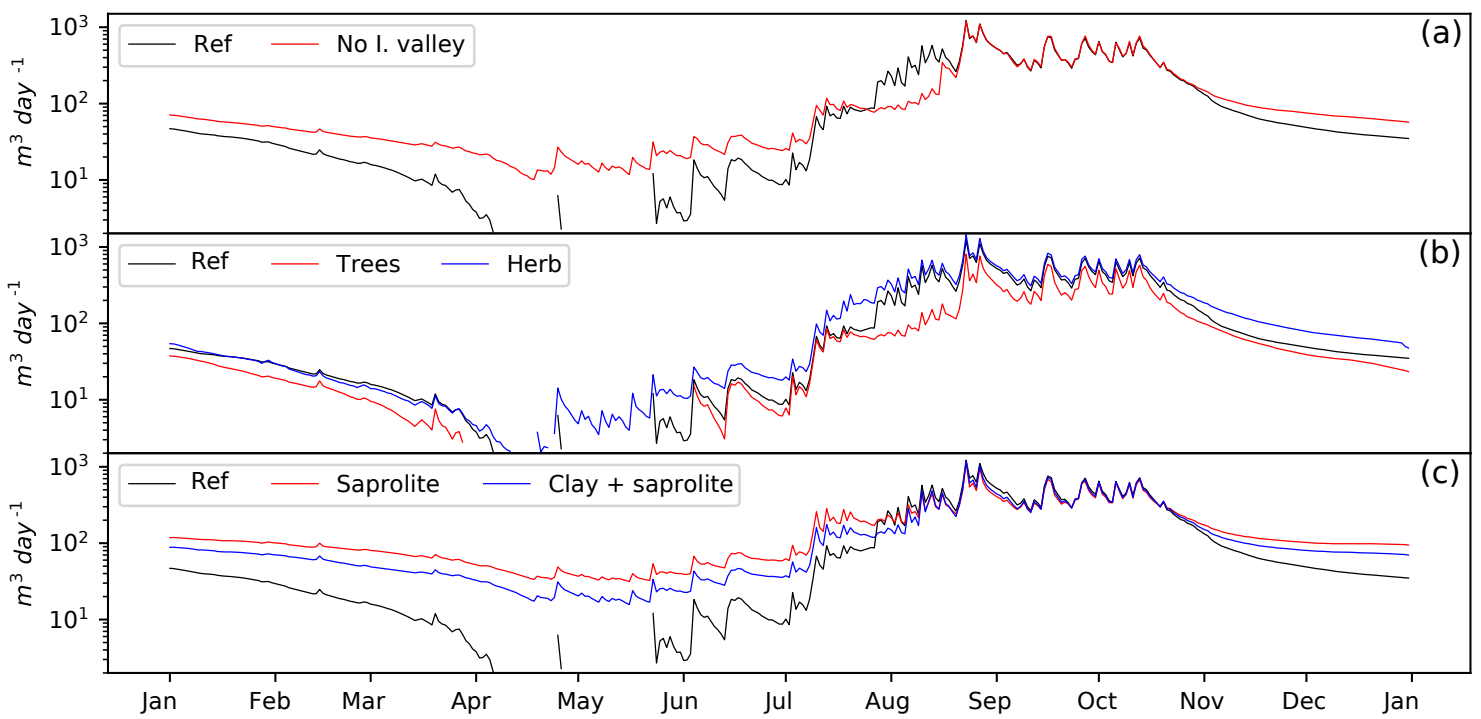

Figure 9. Simulated streamflow of year 2011 for the three virtual experiments. The reference run is always displayed as a black line. In the lower panel, the clay + saprolite refers to the "mixed" case where the H3 layer is made of clayey material on the left bank and saprolite material on the right bank.

ley (around P1; see Fig. 4). This is not seen when the impervious layer is removed (no I. valley experiment), and where only a strong-amplitude permanent water table is present. In the upstream contributive area (around P2, Fig. 10d), no difference is observed.

All vegetation experiments (Fig. 10b, P1) simulate a perched water table in the inland valley. The tree-covered catchment shows a deeper water table than the herbaceouscovered catchment, while the reference simulation shows an intermediate behaviour. In the upstream contributive area (Fig. 10e, P2), the herbaceous cover matches the reference simulation. The strong water table drawdown induced by tree water uptake lowers the water table down within the clay layer, and no more seasonal variations are observed. In fact, the simulation did not even reach an equilibrium state at that point.

When the whole catchment or half of the catchment deeper layer (H3) is saprolite (Fig. 10c), the fissured basement below the inland valley (in H3) fills up and no perched water table is observed. In the upstream contributive area (Fig. 10f, P2), however, there is a strong seasonal water table amplitude (as also shown in Fig. 4) not observed in the clayey, reference simulation.

\section{Discussion}

\subsection{Inland valley}

The presence of the impermeable layer in the inland valley does not influence the yearly water budget much $(1 \%$ - or $2 \%$ - change in the interannual mean for ET - or
$Q)$, although the water table behaviour in the valley thalweg (Fig. 10a) and the spatial pattern of seasonal water storage changes are much different (Fig. 8a, b). The impervious layer prevents vertical infiltration of water below the inland valley, which contributes to the creation of a perched water table. Without the impervious layer, the permanent water table would fill up during the rainy season until it would reach the same depth as that of the perched layer simulated with an impermeable layer, and act similarly. The period when the permanent water table would reach this depth would correspond to the period of matching streamflow in Fig. 9a. Despite little differences in terms of annual water budget, the sustained low baseflow during the dry season in the absence of the inland valley could have significant eco-hydrological consequences downstream. This should be investigated at the scale of larger hydrosystems (like the Upper Ouémé catchment).

In a similar context, Giertz and Diekkrüger (2003) observed a significantly higher total runoff amount and peak flow and a longer runoff period in a catchment containing a larger inland valley area (catchment size: $3.5 \mathrm{~km}^{2}$, inland valley area: $0.19 \mathrm{~km}^{2}$ ) than in a nearby catchment (catchment size: $3.2 \mathrm{~km}^{2}$, inland valley area: $0.07 \mathrm{~km}^{2}$ ), both located in the Sudanian savanna in northern Benin. Although we do not observe significant differences in the water budget, we do observe a longer runoff period. The catchment size may play a role in the differences with the results from Giertz and Diekkrüger (2003), and this could be further investigated. One has to note that the size of the inland valley this study is based on $(0.3 \mathrm{ha})$ is in the low range of inland valley size distribution, following a survey conducted in the area on 817 inland valleys (Giertz et al., 2012). According to 


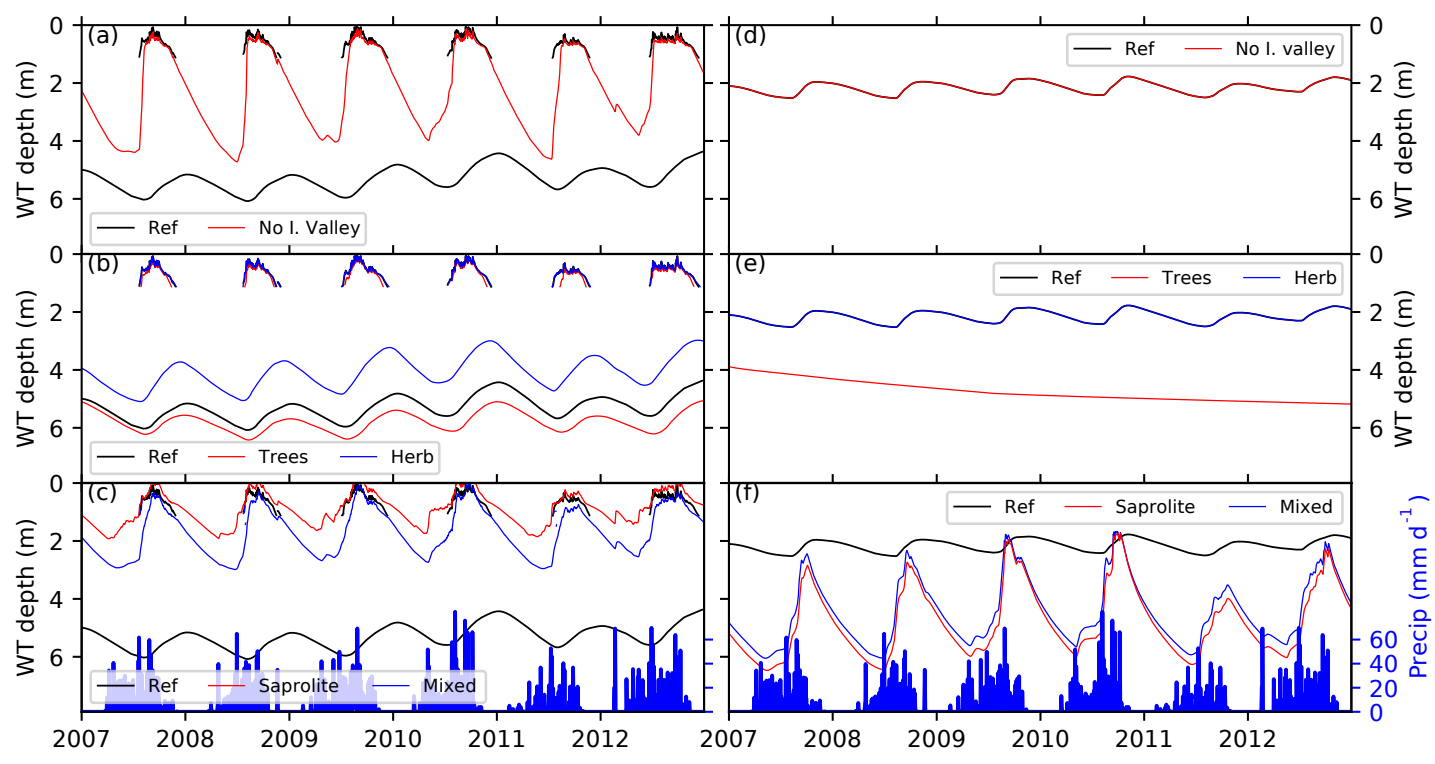

Figure 10. Simulated water table in the valley thalweg $(\mathbf{a}, \mathbf{b}, \mathbf{c})$ at $\mathrm{P} 1$ and in the upper contributive area $(\mathbf{d}, \mathbf{e}, \mathbf{f})$ at $\mathrm{P} 2$.

their study, $18 \%$ of inland valleys have an area lower than 1 ha (and $80 \%$ lower than 10 ha).

\subsection{Vegetation distribution}

The vegetation distribution does influence the yearly water budget. For evapotranspiration, for instance, average yearly amount varies between $74 \%$ and $62 \%$ of the precipitation for, respectively, a fully tree-covered and a herbaceouscovered catchment (68\% for the reference case). The relative difference between trees and herbaceous simulations in average yearly amount is $16 \%$ (with respect to the tree simulation), with a larger difference for dry (24\% for 2011) than for wet (12\% for 2010) years. More importantly, the interannual variability (estimated by the $\mathrm{SD}$ ) is strongly reduced $(26 \%)$ for a tree-covered catchment $(53 \mathrm{~mm})$ as compared to a herbaceous-covered catchment $(72 \mathrm{~mm})$.

Evapotranspiration is higher for the tree-covered catchment, mostly because trees are able to get water from the ground for a longer period than herbaceous cover during the dry season. This is because trees have a longer non-zero LAI period, as they take a short time to renew their leaves and are not impacted by the provoked fires as the herbaceous cover is. They also have access to deeper water thanks to the deeper root system. Finally, trees undergo higher interception and subsequent evaporation thanks to their low-angle leaf orientation and higher LAI and SAI, specified in CLM. Between a herbaceous-covered catchment and a tree-covered catchment, yearly average interception losses increase from $3.2 \%$ to $6.5 \%$ of annual precipitation. Herbaceous cover dries up at the end of the rainy season, and is further burnt by local farmers. When transpiration ceases, evaporation is also limited due to the lack of shallow soil water.
The consequence of a higher evapotranspiration for the tree-covered catchment is a low yearly streamflow budget of $28 \%$ on average as compared to a herbaceous-covered catchment, ranging from $20 \%$ for the wettest year (2010) to $47 \%$ for a dry year (2011). This occurs because during the dry season, when there is no or negligible streamflow, the trees lower the total water storage of the catchment, as shown by the lower simulated water tables (Fig. 10b, e) and the higher seasonal water storage amplitudes (Fig. 8a, c). In the early rainy season, in the tree-covered simulation, rainwater takes a longer time to infiltrate and sufficiently recharge the water table until streamflow finally reaches the streamflow level of the herbaceous-covered simulation (Fig. 9b). This is particularly visible in dry years (i.e. 2011), where highly intermittent rainfall and long dry periods during the rainy season reduce percolation and further delay the "saturated" condition of the catchment.

These results must be tempered by the fact that we used a highly idealized "herbaceous cover", which is, in the actual catchment, a mixture of different vegetation classes (perennial shrubs, isolated trees and perennial and annual grass species, mainly poacea); the same holds for the "trees" case which does not take into account differences among species. For instance, in the Sudanian savanna, a recent case study showed that the woody cover of an agroforestry system transpires less than a forest cover, not only due to lower tree density, but also due to the composition and the physiology of the tree species that are selected in agroforestry practices (Awessou et al., 2016). This effect is only partially taken into account by the forced LAI which is derived from observations that integrates this local variability.

As a consequence, tree covers buffer the hydrological cycle by (1) lowering streamflow, (2) reducing interannual vari- 
ability of evapotranspiration, (3) increasing interannual water storage change by decreasing the water storage during the dry season and (4) increasing interception losses. In the Sudanian savanna, streamflow has decreased since the $80 \mathrm{~s}$, following precipitation decreases, sometimes by twice as much (Descroix et al., 2009). LULC changes occurred simultaneously, mostly by conversion of savanna or woodlands to crops (e.g. Eva et al., 2006). The question of the attribution of the hydrological changes to either climate forcings or LULC changes has not yet been solved. While it is likely that LULC changes have played a minor role since the 80 s (because of the observed streamflow decrease), if the still ongoing deforestation maintains its pace, there is a chance that the hydrological cycle could be significantly altered in the future due to LULC changes. For instance, Yira et al. (2016) used a process-based hydrological model to show that converting savanna to crops in the last 25 years in a Sudanian catchment in Burkina Faso has led to $Q$ increase and ET decrease, a result consistent with this study.

\subsection{Contributive areas}

When sand-like transmissive hydrodynamic properties are set for lateral and upstream areas of the inland valley (the saprolite case, as opposed to the clay-like reference case), the simulation allows the permanent water table to fill up the area below the inland valley (Fig. 10c). This means that simulated seasonal water storage amplitudes are lower in the valley thalweg than in the valley sides (Fig. 8e), showing the opposite pattern to the reference case, where water storage amplitudes are stronger in the valley thalweg (Fig. 8a). Despite these strong spatial differences, the annual water budget exhibits little differences.

In terms of streamflow generation, the subsurface behaviour of the inland valley is rather similar in the saprolite case and the reference case, as whether the shallow perched water table is connected or not to the deeper permanent water table does not matter in its ability to supply the streamflow. In both cases, there is a sufficiently high permeability layer (H2 hardpan layer in the reference simulation, and $\mathrm{H} 3$ in the saprolite-like simulation) which allows lateral transfer to feed the inland valley.

However, although the annual water budgets show little differences, there may still be significant differences in the temporal distribution of fluxes. For instance, the saprolite case sustains a higher baseflow (Fig. 9c). Also, the simulated evaporation differences during the dry season, over herbaceous cover (see Fig. 6d), imply different surface feedbacks on the atmosphere, which may control larger-scale atmospheric features. Evapotranspiration is known to be linked to soil properties through soil moisture availability. Descloitres et al. (2011) showed in the area that evapotranspiration as measured by a large-aperture scintillometer was controlled by soil properties. To check the consistency of these simulated evaporation differences during the dry season, evap-
Table 7. Interannual mean and SD of simulated evapotranspiration $(E T)$, streamflow $(Q)$ and storage $(S)$ for the period 2007-2012 for the reference case and two extreme slope cases.

\begin{tabular}{lllr}
\hline Reference & $839 \pm 64$ & $454 \pm 151$ & $8 \pm 26$ \\
Slope ref $\times 0.5$ & $933 \pm 62$ & $354 \pm 154$ & $14 \pm 28$ \\
Slope ref $\times 2$ & $773 \pm 64$ & $526 \pm 157$ & $1 \pm 21$ \\
\hline
\end{tabular}

otranspiration should be monitored on a hardpan-clay soil profile, as they are widely present in the region. Furthermore, one should note that Fig. $4 \mathrm{a}$ and $\mathrm{b}$ show results from different simulations (reference and saprolite, respectively), although both associated water table levels are real-world data of the same catchment. This means that some features are still missing in the simplified V-shaped model in order to comprehensively reproduce the behaviours of this specific catchment. If a high permeability is set to the valley banks (as in the saprolite simulation), it will result in the filling of most of the valley thalweg by the permanent water table and the absence of the perched water table, which is not observed. On the contrary, in the low-permeability scenario (reference simulation), the simulated water table on the valley banks mismatches the observed data. To successfully match all the observations, lateral variations in the permeability are needed, but this was not the target of this study, which was instead the extraction of the main features and behaviours of inland valleys.

\subsection{Discussion on topographic impacts on water budgets}

The goal of the paper is to derive the controlling factors of inland valley critical zone systems - through virtual experiments - among factors that are either susceptible to evolving (land cover), that characterize inland valleys (thalweg clay lens), or that are still largely unknown (subsurface lithology). In this respect, slopes and topographic effects are not unknowns or susceptible to evolving much (as land cover which has been observed to change significantly, and which is also projected to do so) and are not targets of this study. However, as topography drives lateral flow, catchment slopes may significantly impact the water budgets. We ran two extra experiments, using the reference case and multiplying the slopes by a factor of 2 and a factor of 0.5 to extract the effect of extreme topography ranges found in this environment (Runge, 1991). Table 7 compares the results from these experiments to the reference case and shows that there is weak impact on the interannual variability (SD) but a marked impact on yearly averages. The impact of slopes is comparable to the impact of vegetation distribution (in Table 6: trees case $\sim$ slope ref $\times 0.5$; herbaceous case $\sim$ slope ref $\times 2$ ). Lower slopes (or higher) decrease (or increase) lateral transfers to the benefit (or cost) of evapotranspiration. 


\section{Conclusions}

In this paper, we studied the hydrological functioning of Sudanian inland valleys and their sensitivity to land cover and their main features (pedology of contributive areas, clay lens), through deterministic sensitivity experiments using a physically based critical zone (CZ) model applied on a virtual generic catchment which comprises an inland valley. This is a first approach to try to understand what controls and explains the behaviour of an inland valley.

We first showed that a $\mathrm{CZ}$ model could be used to reproduce the complexity of a small hydrosystem $\left(0.16 \mathrm{~km}^{2}\right)$ as an inland valley and most of observed water fluxes and temporal dynamics as streamflow, evapotranspiration, soil moisture, water table levels, or water storage. In particular, we confirmed that the interannual variability in precipitation $(\mathrm{SD}=225 \mathrm{~mm})$ is mostly compensated by streamflow $(151 \mathrm{~mm})$ and to a lesser extent by evapotranspiration $(64 \mathrm{~mm})$ and water storage changes $(26 \mathrm{~mm})$.

Using numerical experiments comprising different virtual configurations of the catchment, we found that yearly water budgets were almost insensitive to the presence (or absence) of the low-permeability layer commonly found below the inland valley, although intra-seasonal variations in water storage and water table showed marked differences. Early season streamflow was slightly delayed when the low-permeability layer of the inland valley was virtually removed, which corresponds to the time required for water to percolate below the inland valley. Higher water table levels were obtained when infiltration below the inland valley was enhanced, resulting in a low but permanent baseflow during the dry season, which could have a significant impact downstream. This virtual experiment confirms that the observed streamflow dynamics, particularly in the dry season, is partly due to the low-permeability layer, a typical inland valley feature due to the accumulation of clays (Blavet, 1997; Brabant, 1991; Von Der Heyden, 2004).

On the other hand, yearly water budgets were much more sensitive to the vegetation distribution: average yearly ET for a tree-covered catchment $(944 \mathrm{~mm})$ exceeds that of herbaceous cover $(791 \mathrm{~mm})$. ET differences between the two covers vary between $12 \%$ and $24 \%$ of the annual precipitation for the wettest and driest years, respectively. Therefore, the tree-covered catchment produces a yearly streamflow $28 \%$ lower on average than that of a herbaceous-covered catchment, ranging from $20 \%$ for the wettest year to $47 \%$ for a dry year. Trees also buffer interannual variability in ET by $26 \%$. Extensive LULC changes in the last 30 years, resulting in forest and woodland conversion to agricultural lands, still undergoing today, call for closer attention to the distinct roles of climate changes and land cover changes in the resulting hydrological functioning of Sudanian systems.

We also found little sensitivity of the yearly water budget to the hydrodynamic properties of upstream and lateral areas, although they implied completely opposite behaviours in the intraseasonal space-time patterns of water storages and marked changes in water table depths together with different dynamics and amplitudes of fluxes (e.g. streamflow, soil evaporation). Higher water table levels in the valley thalweg, induced by more permeable materials, foster a low but permanent dry season baseflow.

To summarize, it is shown that while vegetation cover significantly changes water budgets, pedological features have much more impacts on intraseasonal hydrological processes (sustained/unsustained baseflow in the dry season, catchment water storage redistribution) than on yearly water budget amounts. Both factors may therefore potentially impact water-dependent ecosystems but also water use as hydropower generation or irrigation from surface water bodies.

This study was limited to an elementary headwater catchment, and results derived here may not apply at larger scales like basins with larger inland valley / catchment area ratios, or different soil profile distributions. Larger-scale models should be run to investigate these effects, and thus largescale spatial features should be mapped, which poses significant issues regarding subsurface structure. Indeed, the in situ measurements of the underground structure are missing and the structure is not directly available through remote sensing products for instance.

Data availability. Forcing data (Meteorological: AMMA-CATCH, 2005a, and precipitation: AMMA-CATCH, 1999) are available in the AMMA CATCH Database, and simulation configuration files as well as simulation outputs are available upon request.

Author contributions. The critical zone is by essence a complex and interdisciplinary object: all co-authors brought their field and disciplinary expertise to this work (data collection, analyses discussions). Particularly, JMC, LS and BH designed the experiments that BH performed.

Competing interests. The authors declare that they have no conflict of interest.

Acknowledgements. The authors would like to thank many people who helped in acquiring, maintaining and processing data and instruments in Djougou: Sarè Tahirou, Frederic Littel, Jean-Daniel Bernard, Bernard Luck, Nicolas LeMoigne, Idrissou Imorou, Emile Pagou, Théo Ouani, Simon Afouda, Maxime Wubda. We would also like to thank the project partners who consented to the use of their infrastructures and provided valuable information and advices: Arnaud Zannou, Jean-Claude Gbodogbé (Direction Générale de l'Eau, Cotonou, Bénin) and Nicaise Yalo (University of AbomeyCalavi, Bénin).

The AMMA-CATCH regional observing system (which is part of the OZCAR research infrastructure in critical zones) was set up thanks to an incentive funding of the French Ministry of Research that allowed pooling together of various pre-existing 
small-scale observing set-ups. The continuity and long-term perennity of the measurements are made possible by continuous IRD funding since 1990 and by continuous CNRS-INSU funding since 2005. This work has been supported by a grant from Labex OSUG@2020 (Investissements d'avenir - ANR10 LABX56). Most of the computations presented in this paper were performed using the Froggy platform of the CIMENT infrastructure (https://ciment.ujf-grenoble.fr, last access: 2 November 2008), which is supported by the Rhône-Alpes region (GRANT CPER07_13 CIRA), the OSUG@2020 labex (reference ANR10 LABX56) and the Equip@Meso project (reference ANR-10EQPX-29-01) of the programme Investissements d'Avenir supervised by the Agence Nationale pour la Recherche. The authors would also like to thank the four anonymous reviewers who helped to improve the final paper.

Edited by: Erwin Zehe

Reviewed by: four anonymous referees

\section{References}

Andriesse, W., Fresco, L. O., Van Duivenbooden, N., and Windmeijer, P. N.: Multi-scale characterization of inland valley agroecosystems in West Africa, NJAS Wagening, J. Life Sci., 42, 159-179, 1994

AMMA-CATCH: AMMA-CATCH: a hydrological, meteorological and ecological observatory on West Africa, IRD, CNRS-INSU, OSUG, OMP, OREME, https://doi.org/10.17178/AMMACATCH.all, 1990.

AMMA-CATCH: AMMA-CATCH observatory: upper Oueme mesoscale site $\left(14000 \mathrm{~km}^{2}\right)$ in the sudanian climate zone, Benin, IRD, CNRS-INSU, OSUG, OMP, OREME, doi:10.17178/AMMA-CATCH.benin, 1996.

AMMA-CATCH: Precipitation dataset (5 minutes rainfall), over the Donga watershed $\left(600 \mathrm{~km}^{2}\right)$, Benin, IRD, CNRS-INSU, OSUG, OMP, OREME, https://doi.org/10.17178/AMMACATCH.CL.Rain_Od, 1999.

AMMA-CATCH: Surface flux dataset (including meteorological data, radiative budget, surface energy, water vapor and carbon fluxes), within the Donga watershed $\left(600 \mathrm{~km}^{2}\right)$, Benin, IRD, CNRS-INSU, OSUG, OMP, OREME, https://doi.org/10.17178/AMMA-CATCH.AE.H2OFlux_Odc, 2005a.

AMMA-CATCH: Soil dataset (soil moisture, temperature, and succion profiles), within the Donga watershed $\left(600 \mathrm{~km}^{2}\right)$, Benin, IRD, CNRS-INSU, OSUG, OMP, OREME, https://doi.org/10.17178/AMMA-CATCH.CE.SW_Odc, 2005b.

AMMA-CATCH: Surface water dataset (river discharge), of the Nalohou watershed (16 ha), Benin, IRD, CNRS-INSU, OSUG, OMP, OREME, https://doi.org/10.17178/AMMACATCH.CE.Run_Odc, 2008.

Ashby, S. F. and Falgout, R. D.: A parallel multigrid preconditioned conjugate gradient algorithm for groundwater flow simulations, Nucl. Sci. Eng., 124, 145-159, https://doi.org/10.13182/NSE96A24230, 1996.

Atchley, A. L. and Maxwell, R. M.: Influences of subsurface heterogeneity and vegetation cover on soil moisture, surface tempera- ture and evapotranspiration at hillslope scales, Hydrogeol J., 19, 289-305, https://doi.org/10.1007/s10040-010-0690-1, 2011.

Awessou, K. G. B., Peugeot, C., Rocheteau, A., Seguis, L., Do, F. C., Galle, S., Bellanger, M., Agbossou, E., and Seghieri, J.: Differences in transpiration between a forest and an agroforestry tree species in the Sudanian belt, Agrofor. Syst., 1-11, https://doi.org/10.1007/s10457-016-9937-8, 2016.

Balek, J.: Hydrology of wetlands in the headwaters of great African rivers, in: Environmental Role of Wetlands in Headwaters, edited by: J. Krecek, and M. Haigh, Earth and Environmental Sciences, 203-210, Springer, Dordrecht, 2006.

Blavet, D.: Hydro-pédologie d'un versant représentatif d'un paysage sur socle granito-gneissique d'Afrique de l'Ouest (Togo): relations avec le comportement d'une plante cultivée, Soil Science PhD, ORSTOM, Montpellier, 1997.

Böhme, B., Becker, M., Diekkrüger, B., and Förch, G.: How is water availability related to the land use and morphology of an inland valley wetland in Kenya?, Phys. Chem. Earth Parts ABC, 84-95, https://doi.org/10.1016/j.pce.2016.03.005, 2016.

Bonsor, H. C., MacDonald, A. M., and Davies, J.: Evidence for extreme variations in the permeability of laterite from a detailed analysis of well behaviour in Nigeria, Hydrol. Process., 28, 3563-3573, https://doi.org/10.1002/hyp.9871, 2014.

Brabant, P.: Le sol des forêts claires du Cameroun: exemple d'étude d'un site représentatif en vue de la cartographie des sols et de l'évaluation des terres, IRD Editions, 1991.

Brouwer, J., Abdoul Kader, H. A., and Sommerhalter, T.: Wetlands help maintain wetland and dryland biodiversity in the Sahel, but that role is under threat: an example from 80 years of changes at Lake Tabalak in Niger, Biodiversity, 15, https://doi.org/10.1080/14888386.2014.934714, 2014.

Brutsaert, W.: Evaporation into the Atmosphere: Theory, History and Applications, Springer Science \& Business Media, 1982

Bullock, A. and Acreman, M.: The role of wetlands in the hydrological cycle, Hydrol. Earth Syst. Sci., 7, 358-389, https://doi.org/10.5194/hess-7-358-2003, 2003.

Cervigni, R., Liden, R., Neumann, J. E., and Strzepek, K. M.: Enhancing the Climate Resilience of Africa's Infrastructure: The Power and Water Sectors, The World Bank, Washington, DC, 2015.

de Condappa, D., Galle, S., Dewandel, B., and Haverkamp, R.: Bimodal Zone of the Soil Textural Triangle: Common in Tropical and Subtropical Regions, Soil Sci. Soc. Am. J., 72, 33-40, https://doi.org/10.2136/sssaj2006.0343, 2008.

Cornelissen, T., Diekkrüger, B., and Giertz, S.: A comparison of hydrological models for assessing the impact of land use and climate change on discharge in a tropical catchment, J. Hydrol., 498, 221-236, https://doi.org/10.1016/j.jhydrol.2013.06.016, 2013.

Dai, Y., Zeng, X., Dickinson, R. E., Baker, I., Bonan, G. B., Bosilovich, M. G., Denning, A. S., Dirmeyer, P. A., Houser, P. R., Niu, G., Oleson, K. W., Schlosser, C. A., and Yang, Z.-L.: The Common Land Model, B. Am. Meteorol. Soc., 84, 10131023, https://doi.org/10.1175/BAMS-84-8-1013, 2003.

Descloitres, M., Séguis, L., Legchenko, A., Wubda, M., Guyot, A., and Cohard, J. M.: The contribution of MRS and resistivity methods to the interpretation of actual evapo-transpiration measurements: a case study in metamorphic context in north Bénin, 
Surf. Geophys., 9, 187-200, https://doi.org/10.3997/18730604.2011003, 2011.

Descroix, L., Mahé, G., Lebel, T., Favreau, G., Galle, S., Gautier, E., Olivry, J. C., Albergel, J., Amogu, O., and Cappelaere, B.: Spatio-temporal variability of hydrological regimes around the boundaries between Sahelian and Sudanian areas of West Africa: A synthesis, J. Hydrol., 375, 90-102, https://doi.org/10.1016/j.jhydrol.2008.12.012, 2009.

Diatta, S.: Les sols gris de bas versant sur granito-gneiss en région centrale de la Côte d'Ivoire?: organisation toposéquentielle et spatiale, fonctionnement hydrologique?: conséquences pour la riziculture, Nancy 1, 1996.

Di Baldassarre, G., Montanari, A., Lins, H., Koutsoyiannis, D., Brandimarte, L., and Blöschl, G.: Flood fatalities in Africa: From diagnosis to mitigation, Geophys. Res. Lett., 37, L22402, https://doi.org/10.1029/2010GL045467, 2010.

Eva, H. D., Brink, A., and Simonetti, D.: Monitoring land cover dynamics in sub-Saharan Africa, 2006.

FAO: Statistical Yearbook 2013: World Food and Agriculture, FAO Food Agric, Organziation U. N. Rome, 2012.

Faure, P. and Volkoff, B.: Some factors affecting regional differentiation of the soils in the Republic of Benin (West Africa), CATENA, 32, 281-306, https://doi.org/10.1016/S03418162(98)00038-1, 1998.

Foken, T.: The Energy Balance Closure Problem: An Overview, Ecol. Appl., 18, 1351-1367, https://doi.org/10.1890/06-0922.1, 2008.

Freycon, V., Wonkam, C., Fayolle, A., Laclau, J.-P., Lucot, E., Jourdan, C., Cornu, G., and Gourlet-Fleury, S.: Tree roots can penetrate deeply in African semi-deciduous rain forests: evidence from two common soil types, J. Trop. Ecol., 31, 13-23, https://doi.org/10.1017/S0266467414000595, 2015.

Gaillardet, J., Braud, I., Hankard, F., Anquetin, S., Bour, O., Dorfliger, N., de Dreuzy, J. R., Galle, S., Galy, C., Gogo, S., Gourcy, L., Habets, F., Laggoun, F., Longuevergne, L., Borgne, T., Naaim, F., Nord, G., Simonneaux, V., Six, D., Tallec, T., Valentin, C., and the OZCAR group OZCAR: the French network of Critical Zone Observatories, Vadose Zone J., in press, https://doi.org/10.2136/vzj2018.04.0067, 2018.

Galle, S., Grippa, M., Peugeot, C., Moussa, I. B., Cappelaere, B., Demarty, J., Mougin, E., Panthou, G., Adjomayi, P., Agbossou, E. K., Ba, A., Boucher, M., Cohard, J.-M., Descloitres, M., Descroix, L., Diawara, M., Dossou, M., Favreau, G., Gangneron, F., Gosset, M., Hector, B., Hiernaux, P., Issoufou, B.-A., Kergoat, L., Lawin, E., Lebel, T., Legchenko, A., Abdou, M. M., MalamIssa, O., Mamadou, O., Nazoumou, Y., Pellarin, T., Quantin, G., Sambou, B., Seghieri, J., Séguis, L., Vandervaere, J.-P., Vischel, T., Vouillamoz, J.-M., Zannou, A., Afouda, S., Alhassane, A., Arjounin, M., Barral, H., Biron, R., Cazenave, F., Chaffard, V., Chazarin, J.-P., Guyard, H., Koné, A., Mainassara, I., Mamane, A., Oi, M., Ouani, T., Soumaguel, N., Wubda, M., Ago, E. E., Alle, I. C., Allies, A., Arpin-Pont, F., Awessou, B., Cassé, C., Charvet, G., Dardel, C., Depeyre, A., Diallo, F. B., Do, T., Fatras, C., Frappart, F., Gal, L., Gascon, T., Gibon, F., Guiro, I., Ingatan, A., Kempf, J., Kotchoni, D. O. V., Lawson, F. M. A., Leauthaud, C., Louvet, S., Mason, E., Nguyen, C. C., Perrimond, B., Pierre, C., Richard, A., Robert, E., Román-Cascón, C., Velluet, C., and Wilcox, C.: AMMA-CATCH, a Critical Zone Observatory in
West Africa Monitoring a Region in Transition, Vadose Zone J., 17, 180062, https://doi.org/10.2136/vzj2018.03.0062, 2018.

Giertz, S. and Diekkrüger, B.: Analysis of the hydrological processes in a small headwater catchment in Benin (West Africa), Phys. Chem. Earth Parts ABC, 28, 1333-1341, https://doi.org/10.1016/j.pce.2003.09.009, 2003.

Giertz, S., Junge, B., and Diekkrüger, B.: Assessing the effects of land use change on soil physical properties and hydrological processes in the sub-humid tropical environment of West Africa, Phys. Chem. Earth Parts ABC, 30, 485-496, https://doi.org/10.1016/j.pce.2005.07.003, 2005.

Giertz, S., Diekkrüger, B., and Steup, G.: Physically-based modelling of hydrological processes in a tropical headwater catchment (West Africa) - process representation and multicriteria validation, Hydrol. Earth Syst. Sci., 10, 829-847, https://doi.org/10.5194/hess-10-829-2006, 2006.

Giertz, S., Steup, G., and Schönbrodt, S.: Use and constraints on the use of inland valley ecosystems in central Benin: results from an inland valley survey, Erdkunde, 66, 239-253, 2012.

Gilbert, J. M., Jefferson, J. L., Constantine, P. G., and Maxwell, R. M.: Global spatial sensitivity of runoff to subsurface permeability using the active subspace method, Adv. Water Res., 92, 30-42, https://doi.org/10.1016/j.advwatres.2016.03.020, 2016.

Gupta, H. V., Kling, H., Yilmaz, K. K., and Martinez, G. F.: Decomposition of the mean squared error and NSE performance criteria: Implications for improving hydrological modelling, J. Hydrol., 377, 80-91, https://doi.org/10.1016/j.jhydrol.2009.08.003, 2009.

Guyot, A., Cohard, J.-M., Anquetin, S., Galle, S., and Lloyd, C. R.: Combined analysis of energy and water balances to estimate latent heat flux of a sudanian small catchment, J. Hydrol., 375, 227-240, https://doi.org/10.1016/j.jhydrol.2008.12.027, 2009.

Guyot, A., Cohard, J.-M., Anquetin, S., and Galle, S.: Long-term observations of turbulent fluxes over heterogeneous vegetation using scintillometry and additional observations: A contribution to AMMA under Sudano-Sahelian climate, Agric. For. Meteorol., 154-155, https://doi.org/10.1016/j.agrformet.2011.10.008, 2012.

Hector, B.: Caractérisation hydrogéophysique multi-échelles et dynamique des stocks d'eau souterrains d'un bassin versant en zone soudanienne de socle (Bénin): apport de la gravimétrie, HydroGeodesy PhD, Université de Strasbourg., 2014.

Hector, B., Seguis, L., Hinderer, J., Descloitres, M., Vouillamoz, J.M., Wubda, M., Boy, J.-P., Luck, B., and Le Moigne, N.: Gravity effect of water storage changes in a weathered hard-rock aquifer in West Africa: results from joint absolute gravity, hydrological monitoring and geophysical prospection, Geophys. J. Int., 194, 737-750, https://doi.org/10.1093/gji/ggt146, 2013.

Hector, B., Hinderer, J., Séguis, L., Boy, J.-P., Calvo, M., Descloitres, M., Rosat, S., Galle, S., and Riccardi, U.: Hydrogravimetry in West-Africa: first results from the Djougou (Bénin) superconducting gravimeter, J. Geodyn., 80, 34-39, https://doi.org/10.1016/j.jog.2014.04.003, 2014.

Hector, B., Séguis, L., Hinderer, J., Cohard, J.-M., Wubda, M., Descloitres, M., Benarrosh, N., and Boy, J.-P.: Water storage changes as a marker for base flow generation processes in a tropical humid basement catchment (Benin): Insights from hybrid gravimetry, Water Resour. Res., 8331-8361, https://doi.org/10.1002/2014WR015773, 2015. 
von der Heyden, C. J. and New, M. G.: The role of a dambo in the hydrology of a catchment and the river network downstream, Hydrol. Earth Syst. Sci., 7, 339-357, https://doi.org/10.5194/hess-7339-2003, 2003.

Hinderer, J., De Linage, C., Boy, J. P., Gegout, P., Masson, F., Rogister, Y., Amalvict, M., Pfeffer, J., Littel, F., and Luck, B.: The GHYRAF (Gravity and Hydrology in Africa) experiment: Description and first results, J. Geodyn., 48, 172-181, https://doi.org/10.1016/j.jog.2009.09.014, 2009.

Hinderer, J., Pfeffer, J., Boucher, M., Nahmani, S., Linage, C. D., Boy, J.-P., Genthon, P., Seguis, L., Favreau, G., Bock, O., and Descloitres, M.: Land Water Storage Changes from Ground and Space Geodesy: First Results from the GHYRAF (Gravity and Hydrology in Africa) Experiment, Pure Appl. Geophys., 169, 1391-1410, https://doi.org/10.1007/s00024-011-0417-9, 2012.

Hinderer, J., Hector, B., Mémin, A., and Calvo, M.: Hybrid gravimetry as a tool to monitor surface and underground mass changes, Int. Assoc. Geod. Symp., 147, https://doi.org/10.1007/1345_2016_253, 2016.

Jones, J. E. and Woodward, C. S.: Newton-Krylov-multigrid solvers for large-scale, highly heterogeneous, variably saturated flow problems, Adv. Water Resour., 24, 763-774, https://doi.org/10.1016/S0309-1708(00)00075-0, 2001.

Kamagaté, B., Séguis, L., Favreau, G., Seidel, J.-L., Descloitres, M., and Affaton, P.: Hydrological processes and water balance of a tropical crystalline bedrock catchment in Benin (Donga, upper Ouémé River), Comptes Rendus Geosci., 339, 418-429, https://doi.org/10.1016/j.crte.2007.04.003, 2007.

Katic, P., Lautze, J., and Namara, R. E.: Impacts of small built infrastructure in inland valleys in Burkina Faso and Mali: Rationale for a systems approach that thinks beyond rice?, Phys. Chem. Earth, 76-78, 83-97, https://doi.org/10.1016/j.pce.2014.11.010, 2014.

Kohler, M. A. and Linsley, R. K.: Predicting the runoff from storm rainfall, US Department of Commerce, Weather Bureau, 1951.

Kollet, S. J. and Maxwell, R. M.: Integrated surface-groundwater flow modeling: A free-surface overland flow boundary condition in a parallel groundwater flow model, Adv. Water Resour., 29, 945-958, https://doi.org/10.1016/j.advwatres.2005.08.006, 2006.

Kollet, S. J. and Maxwell, R. M.: Capturing the influence of groundwater dynamics on land surface processes using an integrated, distributed watershed model, Water Resour. Res., 44, https://doi.org/10.1029/2007WR006004, 2008.

Lachassagne, P., Wyns, R., and Dewandel, B.: The fracture permeability of Hard Rock Aquifers is due neither to tectonics, nor to unloading, but to weathering processes, Terra Nova, 23, 145161, https://doi.org/10.1111/j.1365-3121.2011.00998.x, 2011.

Lawin, A.: Analyse climatologique et statistique du régime pluviométrique de la haute vallée de l'Oueme à partir des données pluviographiques amma-catch benin, Hydrology PhD, INPG, Grenoble, 1 January, 2007.

Le Lay, M. and Galle, S.: Seasonal cycle and interannual variability of rainfall at hydrological scales. The West African monsoon in a Sudanese climate, Hydrol. Sci. J., 50, 509-524, https://doi.org/10.1623/hysj.50.3.509.65029, 2005.

Lebel, T., Cappelaere, B., Galle, S., Hanan, N., Kergoat, L., Levis, S., Vieux, B., Descroix, L., Gosset, M., Mougin, E., Peugeot, C., and Seguis, L.: AMMA-CATCH studies in the Sahelian region of West-Africa: An overview, J. Hydrol., 375, 3-13, https://doi.org/10.1016/j.jhydrol.2009.03.020, 2009.

Lohou, F., Saïd, F., Lothon, M., Durand, P., and Serça, D.: Impact of Boundary-Layer Processes on Near-Surface Turbulence Within the West African Monsoon, Bound.-Layer Meteorol., 136, 1-23, https://doi.org/10.1007/s10546-010-9493-0, 2010.

Lounang Tchatchouang, F. C., Djamfa, R. C., Youta Happi, J., Tchawa, P., and Grozavu, A.: Expansion des cultures de contresaison, changements d'utilisation du sol et les implications environnementales dans les paysanneries de l'Ouest Cameroun, Sci. Ann. Alexandru Ioan Cuza Univ. Iasi Geogr. Ser. Analele Stiintifice Ale Univ. Alexandru Ioan Cuza - Ser. Geogr., 60, 41, 2014.

MacDonald, A. M., Bonsor, H. C., Dochartaigh, B. É. Ó., and Taylor, R. G.: Quantitative maps of groundwater resources in Africa, Environ. Res. Lett., 7, 024009, https://doi.org/10.1088/17489326/7/2/024009, 2012.

Mamadou, O., Cohard, J. M., Galle, S., Awanou, C. N., Diedhiou, A., Kounouhewa, B., and Peugeot, C.: Energy fluxes and surface characteristics over a cultivated area in Benin: daily and seasonal dynamics, Hydrol. Earth Syst. Sci., 18, 893-914, https://doi.org/10.5194/hess-18-893-2014, 2014.

Mamadou, O., Galle, S., Cohard, J.-M., Peugeot, C., Kounouhewa, B., Biron, R., Hector, B. and Zannou, A. B.: Dynamics of water vapor and energy exchanges above two contrasting Sudanian climate ecosystems in Northern Benin (West Africa), J. Geophys. Res. Atmos., 121, 24749, https://doi.org/10.1002/2016JD024749, 2016.

Masiyandima, M. C., van de Giesen, N., Diatta, S., Windmeijer, P. N., and Steenhuis, T. S.: The hydrology of inland valleys in the sub-humid zone of West Africa: rainfall-runoff processes in the M'bé experimental watershed, Hydrol. Process., 17, 1213-1225, https://doi.org/10.1002/hyp.1191, 2003.

Maxwell, R. M.: A terrain-following grid transform and preconditioner for parallel, large-scale, integrated hydrologic modeling, Adv. Water Resour., 53, 109-117, https://doi.org/10.1016/j.advwatres.2012.10.001, 2013.

Maxwell, R. M. and Miller, N. L.: Development of a Coupled Land Surface and Groundwater Model, J. Hydrometeorol., 6, 233-247, https://doi.org/10.1175/JHM422.1, 2005.

Maxwell, R. M., Putti, M., Meyerhoff, S., Delfs, J.-O., Ferguson, I. M., Ivanov, V., Kim, J., Kolditz, O., Kollet, S. J., Kumar, M., Lopez, S., Niu, J., Paniconi, C., Park, Y.-J., Phanikumar, M. S., Shen, C., Sudicky, E. A., and Sulis, M.: Surface-subsurface model intercomparison: A first set of benchmark results to diagnose integrated hydrology and feedbacks, Water Resour. Res., 50, 1531-1549, https://doi.org/10.1002/2013WR013725, 2014.

Maxwell, R. M., Condon, L. E., and Kollet, S. J.: A high-resolution simulation of groundwater and surface water over most of the continental US with the integrated hydrologic model ParFlow v3, Geosci. Model Dev., 8, 923-937, https://doi.org/10.5194/gmd-8923-2015, 2015.

Meyerhoff, S. B. and Maxwell, R. M.: Quantifying the effects of subsurface heterogeneity on hillslope runoff using a stochastic approach, Hydrogeol J., 19, 1515-1530, https://doi.org/10.1007/s10040-011-0753-y, 2011.

Meyerhoff, S. B., Maxwell, R. M., Graham, W. D., and Williams, J. L.: Improved hydrograph prediction through subsurface characterization: conditional stochastic hillslope simulations, Hy- 
drogeol J., 22, 1329-1343, https://doi.org/10.1007/s10040-0141112-6, 2014.

Nyamadzawo, G., Wuta, M., Nyamangara, J., Nyamugafata, P., and Chirinda, N.: Optimizing dambo (seasonal wetland) cultivation for climate change adaptation and sustainable crop production in the smallholder farming areas of Zimbabwe, Int. J. Agric. Sustain., 13, https://doi.org/10.1080/14735903.2013.863450, 2015.

Richard, A.: Caractérisation de la variabilité spatiale des propriétés hydrodynamiques des sols de l'Ouémé supérieur (Bénin)?: Rapport d'analyse, 2012.

Richard, A.: Analyse du cycle hydrologique en climat soudanien au Bénin: vers une modélisation couplée des processus latéraux et verticaux, Hydrology $\mathrm{PhD}$, Université Grenoble Alpes, Grenoble, France, 2014.

Richard, A., Galle, S., Descloitres, M., Cohard, J.-M., Vandervaere, J.-P., Séguis, L., and Peugeot, C.: Interplay of riparian forest and groundwater in the hillslope hydrology of Sudanian West Africa (northern Benin), Hydrol. Earth Syst. Sci., 17, 50795096, https://doi.org/10.5194/hess-17-5079-2013, 2013.

Robert, D.: Caractérisation et modélisation de la dynamique de l'évapotranspiration en Afrique soudanienne en zone de socle, Hydrology PhD, Université Grenoble Alpes, Grenoble, August, 2012.

Rodenburg, J., Zwart, S. J., Kiepe, P., Narteh, L. T., Dogbe, W., and Wopereis, M. C. S.: Sustainable rice production in African inland valleys: Seizing regional potentials through local approaches, Agric. Syst., 123, 1-11, https://doi.org/10.1016/j.agsy.2013.09.004, 2014.

Runge, J.: Geomorphological depressions (Bas-fonds) and present-day erosion processes on the planation surface of Central-Togo/Westafrica, Erdkunde, 45, 52-65, https://doi.org/10.3112/erdkunde.1991.01.05, 1991.

Schmitter, P., Zwart, S. J., Danvi, A., and Gbaguidi, F.: Contributions of lateral flow and groundwater to the spatio-temporal variation of irrigated rice yields and water productivity in a West-African inland valley, Agric. Water Manag., 152, 286-298, https://doi.org/10.1016/j.agwat.2015.01.014, 2015.

Seghieri, J., Do, F. C., Devineau, J.-L., and Fournier, A.: Phenology of Woody Species Along the Climatic Gradient in West Tropical Africa, https://doi.org/10.5772/33729, 2012.

Séguis, L., Kamagaté, B., Favreau, G., Descloitres, M., Seidel, J.-L., Galle, S., Peugeot, C., Gosset, M., Le Barbé, L., Malinur, F., Van Exter, S., Arjounin, M., Boubkraoui, S., and Wubda, M.: Origins of streamflow in a crystalline basement catchment in a subhumid Sudanian zone: The Donga basin (Benin, West Africa): Inter-annual variability of water budget, J. Hydrol., 402, 1-13, https://doi.org/10.1016/j.jhydrol.2011.01.054, 2011.
Srivastava, V., Graham, W., Muñoz-Carpena, R., and Maxwell, R. M.: Insights on geologic and vegetative controls over hydrologic behavior of a large complex basin - Global Sensitivity Analysis of an integrated parallel hydrologic model, J. Hydrol., 519, 2238-2257, https://doi.org/10.1016/j.jhydrol.2014.10.020, 2014.

Sultan, B. and Janicot, S.: The West African Monsoon Dynamics. Part II: The "Preonset" and "Onset" of the Summer Monsoon, J. Climate, 16, 3407-3427, https://doi.org/10.1175/15200442(2003)016<3407:TWAMDP>2.0.CO;2, 2003.

Van Genuchten, M. T.: A closed-form equation for predicting the hydraulic conductivity of unsaturated soils, Soil Sci. Soc. Am. J., 44, 892-898, 1980.

Von Der Heyden, C. J.: The hydrology and hydrogeology of dambos: a review, Prog. Phys. Geogr., 28, 544-564, https://doi.org/10.1191/0309133304pp424oa, 2004.

Vouillamoz, J. M., Lawson, F. M. A., Yalo, N., and Descloitres, M.: The use of magnetic resonance sounding for quantifying specific yield and transmissivity in hard rock aquifers: The example of Benin, J. Appl. Geophys., 107, 16-24, https://doi.org/10.1016/j.jappgeo.2014.05.012, 2014.

Weiler, M. and McDonnell, J.: Virtual experiments: a new approach for improving process conceptualization in hillslope hydrology, J. Hydrol., 285, 3-18, https://doi.org/10.1016/S00221694(03)00271-3, 2004.

Wood, A.: Headwater Wetlands in Eastern and Southern Africa, in Environmental Role of Wetlands in Headwaters, edited by: J. Krecek and M. Haigh, 211-220, Springer Netherlands, 2006.

World Bank: Directions in hydropower, The World Bank, 2009.

Wubda, M., Descloitres, M., Yalo, N., Ribolzi, O., Vouillamoz, J. M., Boukari, M., Hector, B., and Séguis, L.: Time-lapse electrical surveys to locate infiltration zones in weathered hard rock tropical areas, J. Appl. Geophys., 142, 23-37, https://doi.org/10.1016/j.jappgeo.2017.01.027, 2017.

Yira, Y., Diekkrüger, B., Steup, G., and Bossa, A. Y.: Modeling land use change impacts on water resources in a tropical West African catchment (Dano, Burkina Faso), J. Hydrol., 537, 187199, https://doi.org/10.1016/j.jhydrol.2016.03.052, 2016.

Zeng, X.: Global Vegetation Root Distribution for Land Modeling, J. Hydrometeorol., 2, 525-530, https://doi.org/10.1175/15257541(2001)002<0525:GVRDFL>2.0.CO;2, 2001. 